\title{
1. The information systems discipline in Australian universities: a contextual framework
}

\author{
Guy G. Gable \\ Faculty of Information Technology \\ Queensland University of Technology
}

\begin{abstract}
This chapter presents the contextual framework for the second phase of a multi-method, multiple study of the information systems (IS) academic discipline in Australia. The chapter outlines the genesis of a two-phase Australian study, and positions the study as the precursor to a larger Pacific-Asia study. Analysis of existing literature on the state of IS and on relevant theory underpins a series of individual Australian state case studies summarised in this chapter and represented as separate chapters in the book. This chapter outlines the methodological approach employed, with emphasis on the case-study method of the multiple state studies. The process of multiple peer review of the studies is described. Importantly, this chapter summarises and analyses each of the subsequent chapters of this book, emphasising the role of a framework developed to guide much of the data gathering and analysis. This chapter also highlights the process involved in conducting the meta-analysis reported in the final chapter of this book, and summarises some of the main results of the meta-analysis.
\end{abstract}

\section{Introduction}

This book represents the second phase of a multi-method, multiple study of the IS academic discipline in Australian universities (the 'IS-in-Oz' study). In the first phase, drawing on Whitley's theory of scientific change - as encapsulated in a framework proposed by Ridley (2006a) - the study analyses the degree of 'professionalisation' of the IS discipline, the overarching research question being, 'To what extent is IS a distinct and mature discipline in Australia?' Completion of the first phase of the study was marked by publication, in December 2006, of a special edition (vol. 14, no. 1) of the Australasian Journal of Information Systems (AJIS). 


\section{Features of the second phase}

The second phase of the IS-in-Oz study, reported in this book, has sought to address several constraints and limitations in the first phase. To begin with, it was felt that the potential long-term significance of this first examination of the IS discipline across Australia warranted a more permanent documentation of its findings to complement the medium of the AJIS publication. A main aim of the IS-in-Oz study is to initiate a continuing, longitudinal evaluation of the state of the IS academic discipline in Australia. A book offers an appropriate form to set down an initial long-term reference.

A book format also offered the opportunity to extend the work. A limitation of the first phase of the study was that - from necessity rather than choice - the theory framework continued to evolve in parallel with the progress of the individual research tasks. Hence, there was some variation among first-phase papers in relation to application of the theoretical framework. The second phase of the study allowed the researchers to further analyse the data in terms of the more complete theoretical Ridley framework described in Chapter 3.

Articles in the first phase of the study were subject to the standard length constraint of the AJIS. These constraints are eased by describing the research outcomes in a book. A feature of the case studies reported in this volume is the addition of vignettes from selected, significant people in the development of the IS discipline. In the second phase of the IS-in-Oz study, it was decided that the history of the progress of IS in the Australian states could be honoured through brief vignettes of a sample of the men and women who had made major contributions to the advancement of IS in those states.

The first phase of the IS-in-Oz study did not extend to a consolidated analysis across the individual completed sub-studies. In phase two, a group of researchers undertook to examine the individual revised studies, with a view to arriving at an Australia-wide perspective. This analysis sought to evaluate collectively the data from the individual states in relation to the revised Ridley framework. The consolidated analysis also sought to highlight more striking Australian characteristics that emerged from the data but that could not be applied readily to the a priori theoretical framework.

This chapter presents the contextual framework for the study described in this book. As such, it provides an overview to put the following chapters in perspective. The chapter examines the place of the IS-in-Oz study as a pilot and subset of a wider study. It reviews the overall design of the study and the role of the component studies described in individual chapters of this book. Finally, it provides the reader with some understanding of the main focus of each of the sub-studies described in the following chapters. 


\section{The 'parent' IS in Pacific-Asia study (IS-in-PA) design}

This Australian study was derived from a broader study of the state of the IS academic discipline in Pacific-Asia ('IS-in-PA'), the results of which have been published in a special issue of Communications of the AIS (CAIS). Note that the Association for Information Systems (AIS) - the main international association of IS academics, and sponsor of the IS-in-PA study-organises its activities around three world regions: 1) the Americas; 2) Europe, Africa and the Middle East; and 3) Pacific-Asia. Figure 1.1 depicts the main components of the 'parent' IS-in-PA study. The Pacific-Asia study (and its component Australian study) is motivated by a recognition that IS as an academic discipline has evolved differentially around the world. For example, there is regional variation in the strength of its presence as an academic discipline; it could take on identifiably different local forms - for example, from a soft-systems emphasis to a more technical focus; there could be regional differences in topics taught and researched (as was observed across Europe by Avgerou et al. 1999).

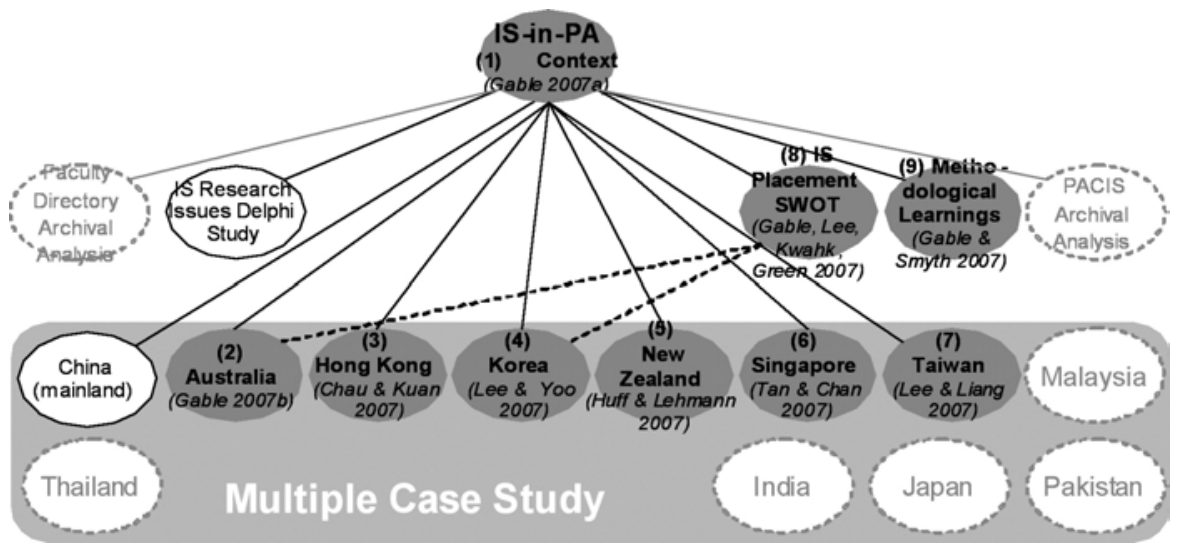

Figure 1.1 The IS in Pacific-Asia region study (IS-in-PA)

The IS-in-PA study includes nine main study components (see Figure 1.1), the principal of which is a multiple case study across six states of the Pacific-Asia (PA) region. It was decided early on to restrict the first iteration of the IS-in-PA study to those areas in the region where IS is relatively more visible internationally - Australia, Hong Kong (China), Korea, New Zealand, Singapore and Taiwan - the intent being in future to extend the study incrementally to other parts of the region (the study is currently being extended to Mainland China, with study initiation also in place in Japan, India, Malaysia, Pakistan and Thailand, for which tentative state study team leaders have been identified). Table 1.1 lists the main IS-in-PA study leaders. 
Table 1.1 The IS in Pacific-Asia (IS-in-PA) study team

\begin{tabular}{l|l}
\hline State & Study leader \\
\hline Australia & Professor Guy G. Gable, Queensland University of Technology \\
\hline Hong Kong (China) & Professor Patrick Chau, University of Hong Kong \\
\hline Korea & Professor Jae-Nam Lee, Korea University \\
\hline New Zealand & Professor Sid Huff, Victoria University of Wellington \\
\hline Singapore & Professor Bernard Tan, National University of Singapore \\
\hline Taiwan & Professor T. P. Liang, National Sun Yat-Sen University \\
\hline
\end{tabular}

The IS-in-PA and the IS-in-Oz studies have, from the outset, been designed and executed with the expectation that they will be extended and repeated over time. Shaded ovals in Figure 1.1 represent those components that were completed in the first execution, with the detailed Australian results reported in a special issue of AJIS. Unshaded ovals represent components that are in progress - for example, Mainland China Case Study, IS Research Issues Delphi Study-and dashed ovals represent planned components soon to begin (note that further study components are expected to evolve).

\section{The phase one Australian study (IS-in-Oz) design}

A meeting of a subgroup of the IS-in-PA study team in Auckland in January 2004 (Gable, Huff and Felix Tan, Auckland University of Technology, who was then the elected AIS Region 3 Council Representative) resulted in a proposal to conduct a multiple-case study of the Australian states - the IS-in-Oz study. Table 1.2 lists the main IS-in-Oz study team members. The components of the IS-in-Oz study are shown in Figure 1.2. Shaded ovals represent those components that were reported in the special issue of AJIS. Unshaded ovals represent components that were in progress at the time of the AJIS special issue. Initial findings of the IS Research Issues Delphi Study have since been reported elsewhere. Preliminary results of the Australasian Conference on Information Systems (ACIS) Archival Analysis are now available and are included later in this chapter rather than reported as a separate chapter.

The IS Research Issues Delphi Study - represented as an unshaded oval in Figure 1.1 and again in Figure 1.2 - is an international study of the key issues facing IS researchers. The first round of this study resulted in 266 responses, articulating a total of 1241 issues. Analysis of these issues resulted in a comparatively succinct set of 56 issue statements being synthesised for presentation to IS researchers in the second round of the study. The second round of the study in March 2005 yielded more than 800 responses. Various results from this sub-study, although not reported in this book, have been presented at several workshops in Australia, Hong Kong and Shanghai, and as keynotes at the AIS SIG IS in Asia Pacific (ISAP) of ICIS 2005, and at the Information Systems and Management track (ISM '07) of the IEEE WiCOM 2007 conference in Shanghai (Gable, Stark and Smyth 2007). 
Table 1.2 The IS in Australia (IS-in-Oz) study team

\begin{tabular}{|c|c|}
\hline Home state & Team member \\
\hline \multirow[t]{2}{*}{ Queensland } & Professor Guy G. Gable, Queensland University of Technology \\
\hline & Dr Robert Smyth, Queensland University of Technology \\
\hline \multirow{4}{*}{$\begin{array}{l}\text { Australian } \\
\text { Capital } \\
\text { Territory }\end{array}$} & $\begin{array}{l}\text { Dr Roger Clarke, Principal, Xamax Consultancy Pty Ltd; Visiting Professor, The Australian } \\
\text { National University }\end{array}$ \\
\hline & Professor Shirley Gregor, The Australian National University \\
\hline & Professor Ed Lewis, Australian Defence Force Academy, University of New South Wales \\
\hline & Associate Professor Craig McDonald, University of Canberra \\
\hline \multirow{3}{*}{$\begin{array}{l}\text { New South } \\
\text { Wales }\end{array}$} & Professor Ernest Jordan, Macquarie University \\
\hline & Dr Jim Underwood, University of Technology, Sydney \\
\hline & Associate Professor David Wilson, University of Technology, Sydney \\
\hline \multirow{3}{*}{$\begin{array}{l}\text { South } \\
\text { Australia }\end{array}$} & Professor Andy Koronios, University of South Australia \\
\hline & Associate Professor Mike Metcalfe, University of South Australia \\
\hline & Professor Paula Swatman, University of South Australia \\
\hline Tasmania & Dr Gail Ridley, University of Tasmania \\
\hline \multirow[t]{3}{*}{ Victoria } & Dr Elsie Chan, Australian Catholic University \\
\hline & Associate Professor Carol Pollard, Appalachian State University \\
\hline & Professor Graeme Shanks, Monash University \\
\hline \multirow{4}{*}{$\begin{array}{l}\text { Western } \\
\text { Australia }\end{array}$} & Professor Janice Burn, Edith Cowan University \\
\hline & Dr Chad Lin, Curtin University of Technology \\
\hline & Professor Graham Pervan, Curtin University of Technology \\
\hline & Professor Craig Standing, Edith Cowan University \\
\hline
\end{tabular}

There are 12 shaded ovals in Figure 1.2, corresponding with the 12 completed IS-in-Oz sub-studies reported in the December 2006 special edition of the AJIS. These include three conceptual papers ('The contextual framework', 'The history' and 'The theory base') and nine empirical papers (seven state case studies, a research survey and a 'contradictions' piece).

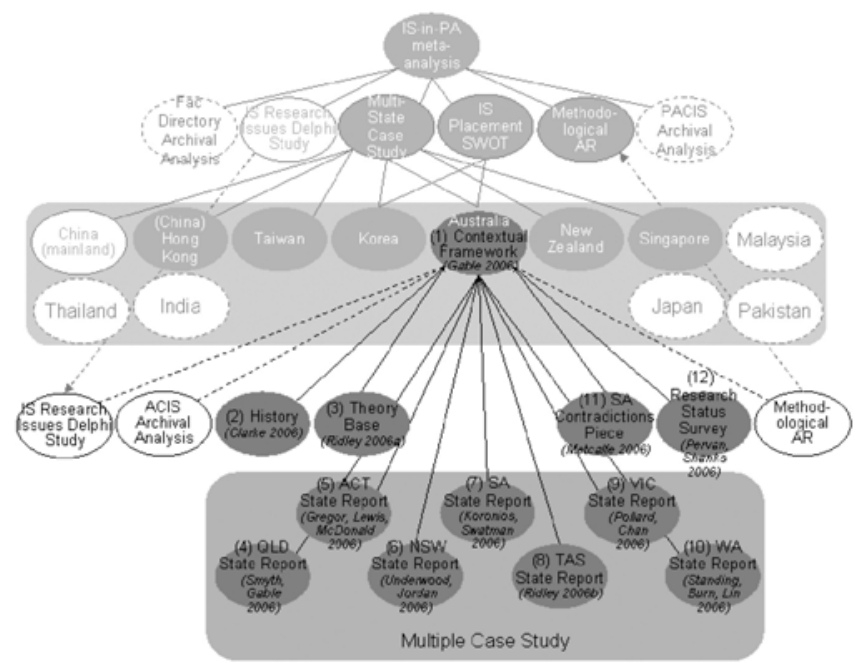

Figure 1.2 The IS in Australia (IS-in-Oz) study 
Phase one of the IS-in-Oz study sought to draw on and complement other studies of the state of the IS discipline, notably those of Avgerou et al. (1999) in Europe, and Pervan and Shanks (2004) in Australia. The phase one IS-in-Oz study-being exploratory and descriptive, and to some extent a pilot - did not begin from a highly specific theory base. The Ridley (2006a) theory base evolved throughout the study, largely in parallel with and somewhat influenced by the study.

A key study aim was to evolve and apply (and 'test') a process of evidence collection and review, for future extension and possible replication within the region and across other world regions. This was to some extent addressing past concerns expressed - for example, by Phillip Ein-dor (Gable 2002) — about the lack of a methodology and indicators for tracking diffusion of the IS discipline. It was posited that the establishment of measures and indicators of the state of IS, and a baseline snapshot of its current state, would facilitate tracking of the state and monitoring the effect of initiatives to promote IS as a discipline. While emphasis here is on Australia, many of the ideas, mechanisms and aims are generalisable to all AIS regions. Thus, one overarching aim of the study is to contribute to a general methodology with which to describe and monitor the evolving state of the IS discipline in any region or country. Other more specific study aims included:

- to begin documenting characteristics of IS programs across universities in Australia

- to begin documenting characteristics of IS research across universities in Australia

- to begin assessing the strength of the IS presence in Australian universities

- to evaluate the maturity of IS as an academic discipline in Australia (as per the theory base)

- to identify emerging trends in IS in Australian universities

- to identify the main influences on IS in Australian universities.

\section{Study questions in phase one of the IS-in-Oz study}

Study questions and the units of analysis (sometimes the university; sometimes the state) evolved over time - along with the study design — with varying emphasis across the sub-studies.

Broad study questions implicit in the final case study protocol include:

- what is the relative size of the IS presence at the university

- what is the administrative placement of IS (including changes over time)

- to what extent has IS at the university been impacted on by local contingencies

- to what extent is IS identified as a separate field at the university

- what are the distinctive features of the IS curriculum at the university

- what are the distinctive features of IS research at the university 
- who are the key people who have had an impact on IS in universities in the state?

The protocol includes a long list of more specific questions, based on each of these broad questions. The state teams varied in their reliance on the protocol.

Questions posed to intrastate reviewers of the state reports included:

- what do you believe to be the main challenges facing the IS academic discipline in your state today?

- what do you believe to be the main opportunities facing the IS academic discipline in your state today?

The next section briefly reviews literature on past studies of the IS discipline and relevant theory. The subsequent section summarises the overall study approach, with emphasis on repeatability - a key study aim. Overall study outcomes are then related. The final section describes study limitations and potential further research.

\section{The literature}

\section{Past studies of the IS discipline}

Articles discussing the state of IS tend to revolve around one of several themes: 1) the identity crisis within IS; 2) IS as an academic field; 3) the state of IS research; and 4) the evolution of the field of IS. (This section offers a very brief overview of past studies of the IS discipline. Individual chapters in this book make more specific reference to relevant literature.)

One dominant theme is the existence or otherwise of an identity crisis within IS, the concern being that the discipline's central identity is ambiguous (Benbasat and Zmud 2003). There are several articles debating the core and scope of IS. The debate in recent times culminated in a series of 11 articles published in the Communications of the AIS (CAIS). This is an important debate, as the degree of convergence of a discipline can have political implications. 'Convergent communities are favourably placed to advance their collective interests since they know what their collective interests are, and enjoy a clear sense of unity in promoting them' (Becher 1989:160).

The academic field of IS is another recurring theme. Avgerou et al. (1999) comprehensively discuss the academic field of IS in Europe, while other authors tend to focus on one area: the status of IS as an academic discipline (Introna 2003; Khazanchi and Munkvold 2000); IS educational programs (Ang and Jiwahhasuchin 1998; Lo 1989); or the location of IS departments in universities (Sherer 2002).

Articles on the state of IS research include: paradigmatic and methodological examinations of IS research (Chen and Hirschheim 2004; Orlikowski and Baroudi 
1991; Vessey et al. 2002); regional differences in IS research (Evaristo and Karahanna 1997); and themes of IS research (Bacon and Fitzgerald 2001; Palvia et al. 2004).

There are two types of articles on the evolution of IS: those that assess the current status of the field by tracing its historical evolution and the driving forces that shape it (Adam and Fitzgerald 2000), and those that gauge the status of IS development and evolution by examining changes over time in topics, themes and research strategies in the literature (Alavi and Carlson 1992; Claver et al. 2000; Farhoomand and Drury 1999).

\section{Relevant theory}

The study reported in this volume (as well as the phase-one study reported in AJIS) aims to investigate the IS academic discipline in Australia from historical and current perspectives, collecting evidence across a range of dimensions. To maximise the descriptive potential of the study, the results need to be capable of integration, so that the relationships within and across the dimensions and geographical units are understood. A meaningful theoretical framework helps relate the results of the different dimensions of the study to characterise the discipline in the region, and assist in empowering the Australian IS research community. The Ridley theory chapter (Chapter 3) reviewed literature on the development of disciplines, before deriving a theoretical framework for the broader study reported elsewhere in this book. The framework considered the current and past state of IS in Australian universities from the perspective of the development of a discipline. The components of the framework were derived and validated through a thematic analysis of the IS and non-IS literature. The framework developed in the Ridley paper - which has been guided partly by Whitley's theory of scientific change (1984a, 1984b) — was used to analyse data collated from the Australian regions.

\section{Study approach}

In this section, study logistics are described. The overall study design is reflected in Figure 1.2. Sub-study methods and methodology are addressed in the individual chapters of the volume. Some details of the case-study method are included below in order to avoid repetition across the seven state case reports.

\section{Overview}

The study process was a combination of deductive, top-down broad definitions of aims, questions and procedures, and inductive, bottom-up consideration of sources of evidence, project resources and feasibility. It could be said that early results were mainly inductive, these being followed by a more deductive, top-down review. 


\section{Project management}

Individual state teams managed their respective case studies, with the overall project managed by Guy Gable (project leader) and Bob Smyth (project manager). The main mechanisms of project management were: 1) a project web site; 2) regular status meetings of the project leader and project manager and related project status reporting by e-mail; 3) face-to-face team meetings when feasible (on several occasions in conjunction with ACIS or the Australian Council of Professors and Heads of Information Systems [ACPHIS]); 4) several teleconference and Skype sessions, as a cost-effective alternative to face-to-face meetings; 5) the case-study protocol served as a valuable mechanism for coordinating the study teams.

\section{Complexities and issues encountered}

A range of complexities was encountered throughout the study, some of which were fully or partially overcome; others of which were not. Several pertained to the scope and object of the study: academia versus the profession versus both; teaching versus research; past versus present. There was discussion about the utility of 'state'-based case studies, it being mooted that other groupings of institutions might be more meaningful: for example, 'Sandstone' universities versus the others; large IS versus small IS - that is, based on numbers of undergraduate IS students).

\section{Extending the phase-one study}

At a meeting convened by Gable in Canberra shortly before publication of the December 2006 special edition of the AJIS, the possibility of extending the study was raised. The meeting agreed that a book would allow the results of the research to be available in a more permanent form - a desirable situation given the potential value of the studies to the IS discipline and given the plan to replicate the study over time. It was agreed that researchers who had authored papers in the AJIS special edition be invited to participate in this second phase.

Subsequently, 17 of the 18 researchers who had contributed to the AJIS special edition agreed to contribute to the second phase; only the second South Australian study, conducted by Metcalfe, was not taken to phase two. An additional contributor, however-Wilson-agreed to prepare an alternative view of IS in New South Wales, as a counterpoint to the earlier findings published in AJIS. As described earlier in this chapter, the extensions in phase two involved a new analysis of the state data in relation to the extended Ridley framework; they also provided for expanding on earlier material and focusing on a sample of important contributors to the development of the IS discipline, via selected vignettes. 


\section{The state case studies}

The case studies were largely exploratory and descriptive, with relatively less emphasis on interpretation and the ability to be generalised. The case-study approach is well suited for investigation where there is little established theory on the topic (Yin 2003). The case-study method also has the advantage of allowing the researcher to develop a good feeling for the complexities of interacting forces and subtleties that are more difficult to detect with other methods. Walsham (1995) refers to the 'rich insight' possible from the case-study approach.

\section{Team data gathering}

The data collected in the case studies focused on questions implicit in the case-study protocol, as described earlier. It was planned that team members in Australian states and territories (referred to collectively as the study 'states') would gather qualitative data about each university (as well as relevant state-level data). The case-study method was agreed to as the research approach for the team study. The data gathered were intended to provide insights into the distinctive characteristics of IS in each university in relation to: the degree of administrative autonomy, size and influence, curriculum, research, local influences and significant people shaping IS at that university. Anchoring the data gathering and analysis in phase one was Gail Ridley's (2006a) evolving draft framework derived from theory on the emergence of disciplines. Team members in each state sought to analyse the data across the universities engaged in IS in that state, and to present general observations on the features of IS as an academic discipline in that state. Phase two provided further analysis of this state data, taking account of the updated version of Ridley's framework described in Chapter 3 of this volume. Phase two also entailed a consolidated analysis of the data from the study.

\section{The protocol}

Yin (2003) argues for the use of a case-study protocol to guide any study employing the case-study method. To this end, study team members developed a multi-state case-study protocol. An abridged version of the protocol is included in Appendix 1.1. A detailed version of the protocol was reported in the AJIS (Smyth and Gable 2006). It was intended that use of the protocol would contribute to:

- comparability across the states

- consistency across the individual case studies

- efficiency in the conduct of the case studies, with potential for data gathering and some analysis being delegated to research assistants or other junior researchers. 
Yin (2003) strongly favours building a protocol around relevant theory. In this study, the protocol relies on a framework, the emergence of a discipline, developed by Ridley and articulated in preliminary form in the 2006 special edition of AJIS, and in expanded form in Chapter 3 of this volume.

Also, many of the tenets of general systems theory (Ackoff 1971) are implicit in the approach to data gathering and the themes and questions documented in the multi-state case-study protocol. The approach to data gathering advocated - based on semi-structured interviews utilising broad themes to tap the perceptions of interviewees - is consistent with general systems theory. This approach permits the researcher to take a more holistic approach to the topic, and allows the interviewee to touch on the multiplicity of interacting factors that might contribute to the distinctive characteristics of the IS presence in each university. The protocol directs the researcher to just some of the potential interacting factors that might determine the distinctive characteristics of IS at a given university: that the interaction of geography, the administrative structure and individuals from within and outside the university could, over time, influence curriculum and research at that university. This planned concern for pursuing a holistic view by calculated consideration of factors beyond those suggested by the guiding framework proved useful in the subsequent consolidated analysis of state data.

\section{Mechanisms to increase representativeness}

Given the descriptive and exploratory character of the overall study, the team harboured no illusions regarding the ultimate completeness of issues to be identified, related evidence to be gathered and analyses to be conducted. It was acknowledged that the study offered a mere starting point for continuing monitoring of the state of IS in Australia. Regardless, efforts were made to achieve some level of representativeness of the evidence and perspectives reported. Key mechanisms were: 1) selection of the study team; 2) review of draft state reports by interviewees; 3) review of state reports by intrastate experts; and 4) global review of the draft special issue by appropriate experts.

\section{Selection of the study team}

In establishing the study team, Australia-wide representation was sought; this suggested state-based case reports. Senior and long-standing IS academics were approached; in most cases, those contacted first welcomed involvement but with some changes to the composition of the team over the course of the study.

\section{Review of draft state reports by interviewees}

All interviewees received an early draft of the state report in which their views were recounted. Feedback was channelled through the project manager back to the state teams, and the state teams implemented changes. 


\section{Intrastate reviewers}

In addition to careful review by state team members, interviewees, the project leader and the project manager, each state report was given further local exposure in draft form before wider circulation to cross-case reviewers. Selected 'local experts' were sent a copy of the draft report for review, the aims being to:

- minimise potential adverse reaction from perceived misrepresentation

- try to ensure the report was as representative of the state as possible

- enrich the report with further insights

- ensure that the process of peer review resulted in chapters of a strong academic standard.

\section{Global reviewers}

Two senior and internationally notable IS academics, Iris Vessey and Bernard Glasson, were sent a draft of the complete phase-one output - as prepared for the AJIS 2006 special issue - and were requested to review the material and respond to a brief set of questions pertaining to the historical evolution of IS-in-Oz, the current state and the possible future of IS-in-Oz. The aims of this survey included: 1) gathering further insights; 2) accounting for diverse perspectives; 3) keeping the study team accurate and seeking balance (soliciting third-party reactions to our areas of emphasis and our interpretations); and 4) maximising rigour.

\section{Apologies for omissions or oversights}

Though extensive measures have been pursued to ensure representative input and a balanced report, resource and time limitations have constrained what is possible. While such a report will unavoidably reflect certain emphases and biases and choices made at all stages of its production, the team nonetheless apologises for any omissions or oversights. Given the desire that this study be replicated in future, feedback on any such omissions or oversights is all the more welcome.

\section{Methodological action research}

The overall study effort was compounded substantially by the intention to document the approach for repeatability. Alvesson and Sköldberg (1999) use the term 'reflexive methodology' to refer to an evolutionary approach that aims to maximise the quality of study results. We prefer the term 'methodological action research' (MAR) whereby, in addition to results in relation to research questions posed, the study seeks generalisable contributions to knowledge as regards the research process. We define MAR as:

an action research approach to studying the process of research; it is a reflexive process of progressive problem solving led by individual 
researchers, possibly working with others in a team, to improve the way they address research issues and solve research problems. MAR is conducted above and behind the main research activity, with the researcher, on this second level, observing themselves (and their team) and their experience of the research process, the intent being to better understand and improve that process and to document related methodological learnings.

We therefore sought to establish a highly systematised and proceduralised approach, readily extended and repeatable across other countries and regions (and publication collections - for example, conferences or journals; see ACIS Archival Analysis in Figure 1.2). Note that there is a dotted arrow pointing up from the MAR oval in Figure 1.2 to a similar study at the IS-in-PA level of that figure. This reflects how MAR learning on the IS-in-Oz study informed the parent study by evolving, recording and piloting various methods, mechanisms, concepts and interpretations. It is noted that several of the IS-in-Oz research instruments and approaches needed only marginal adaptation for the purposes of the IS-in-PA study. It is noted also that much of the MAR learning from the IS-in-Oz study was reported in the 'Methodological learnings' article in the CAIS special issue (Gable and Smyth 2007).

\section{Study overview}

This section summarises the 12 chapters of this volume.

\section{The IS discipline in Australian universities: a contextual framework}

The contextual framework introduces the IS-in-Oz study, and the book, including background on study rationale and motivation, a summary of the study aims and conceptual design and main outcomes. Contributions include a cogent synthesis of the literature on previous studies of the IS academic discipline. The approach described offers valuable methodological guidance for the replication and extension of the overall study approach within Australia, the region and to other world regions, and represents one of few attempts to study methodically the evolution of a discipline. With 18 core team members in 12 sub-study teams, and in excess of 50 interviewees and a similar number of reviewers across Australia, the study serves also as a useful example of large-scale research project management. Most importantly, the contextual framework offers a meta-view of the underpinning sub-studies.

\section{A retrospective of the IS discipline in Australia}

In Chapter 2, Clarke, referring to three main eras, offers cogent discussion of the evolution of the IS discipline in Australia, suggesting that it did not follow on from development overseas, but rather emerged in parallel. During the 
'emergence era' (up to 1965), a highly consequential federal government initiative was the Programmer-in-Training (PIT) scheme (from 1963), the syllabus of which emphasised systems analysis and design, and which produced hundreds of ultimately influential senior managers in the public and private sectors.

Early in the 'establishment era' (1965-73), departments were created in colleges of advanced education (CAEs) to assist practice with the application (particularly application development) of computers in business and government. In parallel, topics about how to apply the technology began to emerge in university accounting departments - these being relatively more concerned with the 'information' than with the system. The transfer of PIT to CAEs towards the end of this era heralded formalised IS education, which expanded to institutes of technology. Much of this early effort was service teaching, with IS in universities migrating forward from 'undergraduate service topics and units to sub-majors, majors and only later postgraduate teaching and research'.

At the outset of the 'consolidation era' (1974-90), the University of New South Wales (UNSW) appointed the first Professor of Information Systems, Cyril Brookes, and formed the first university IS department. In 1978, the first Australian was awarded a PhD in IS (Ron Weber at Minnesota under Gordon Davis's supervision). Weber was the second professor of IS (in 1981), with several further such appointments in the late 1980s and about 20 in the 1990s, resulting in more than 30 IS professors by 2005. Early published curricula from the United Kingdom and the United States was too comprehensive and either too computer-science or business-oriented for the mostly IS service subjects being taught; the 'local' IS curriculum thus sometimes became almost insular. Long-awaited recognition of IS within the Australian Computer Society (ACS) Accreditation Guidelines (Clarke and Lo 1989) proved to be a watershed - their core body of knowledge in 1990 evidencing 50 per cent IS content.

Clarke suggests that during the 1970s and the 1980s the vigour of the discipline in the United States resulted in that country establishing leadership in the IS discipline. Philosophies and methods of research were debated through this period, with some acceptance of pluralism. Clarke (in Maynard 1992) depicts IS as occupying 'space between the technical and business disciplines, encompassing a range of applied and instrumentalist topics, and interacting closely with many other disciplines and sub-disciplines'.

Clarke lists seven main clusters of topics or themes in Australian IS since 1965 (with much cross-fertilisation among the themes): 1) technology as enabler and driver; 2) applications of technology; 3) data management; 4) organisations; 5) systems thinking; 6) business-school thinking; and 7) information management. The apparent diversity of curricula and research domains appears perhaps more varied even than that of Europe or the United States. 
Clarke's chapter reveals the slow emergence of a governance framework for the IS discipline in Australia, relative to the growth of the discipline itself. He points out that until 1990 the ACS guidelines for accreditation of tertiary-level courses made no specific provision for IS courses (as distinct from computer science courses). He observes also, however, that a person from an IS background has been president of the ACS for 34 of its 40 years' existence. Clarke observes that none of the business professional groups sought to assume a governance role over IS in Australia and that the business-oriented professional group, the Australian Institute of Systems Analysts (AISA), after prominence in the 1970s, ceased to have a role in IS governance in Australia. In 1990, the first Australian Conference in Information Systems (ACIS) was held, but it was not until 1994 that the AJIS was established. The ACPHIS was formally established in 1995; however, it was not until 2001 that an Australian chapter of the Association for Information Systems (AIS) was established.

\section{Characterising academic IS in Australia: developing and evaluating a theoretical framework}

Ridley's theoretical explorations are based on a review of the literature on the development of disciplines, ultimately deriving a theoretical framework for the broader study. The framework considers the current and past state of IS in Australian universities from the perspective of the development of a discipline. The components of the framework were derived and validated through a thematic analysis of the IS and non-IS literature. In the revised version of the framework employed for this second phase of the study, Ridley proposes that maturity of a discipline is characterised by the development of a core body of knowledge for the discipline and by the establishment by practitioners of that discipline of strong mechanisms of control leading to enhanced reputations and critical rewards. The framework also proposes that the degree of professionalism is inversely proportional to the extent to which a discipline responds to local contingencies. This ad hoc framework was applied as a guide to the collection and analysis of the state data.

The next seven studies are 'state' case studies, for Queensland, the Australian Capital Territory, New South Wales, South Australia, Tasmania, Victoria and Western Australia.

\section{The IS discipline in Queensland, 2006}

Data was gathered from all nine universities in Queensland (including the Australian Catholic University, which has common approaches in all its Australian campuses), as all teach IS on at least one campus (Table 1.3). The study found that the condition of IS in Queensland reflected the highly decentralised nature of the state. Relative to its population, Queensland has a large number of universities, each of which is engaged in IS teaching and research. The study 
reveals little evidence of a distinctive Queensland flavour of IS; rather, there is a diversity of curriculum approaches and an equally broad range of research topics and methods. Two of the state's regional universities are notable for the relative strength of their IS presence - in terms of the number of IS staff, the number of IS students and the range of campuses across which IS is taught. The breadth of topics and approaches to IS in Queensland is evidenced by the existence of separate, competing IS groups in each of two of the largest universities; in each case, one of the IS groups is highly technical in orientation while the other is business oriented. Across the eight Queensland universities, there is wide variability in terms of the administrative location of the IS academic staff in the university structure.

Table 1.3 Placement of the IS academic discipline in Queensland universities

\begin{tabular}{c|c|c|c|c|c|c|c|c|c}
\hline & & & \multicolumn{3}{|c|}{ Location of IS within the university } & \multicolumn{3}{c}{ Generic levels } \\
\hline Era & Type & University & $\begin{array}{c}\text { First level } \\
\text { down }\end{array}$ & $\begin{array}{c}\text { Second } \\
\text { level down }\end{array}$ & $\begin{array}{c}\text { Third level } \\
\text { down }\end{array}$ & $\begin{array}{c}\text { Fourth } \\
\text { level down }\end{array}$ & First level & $\begin{array}{c}\text { Second } \\
\text { level }\end{array}$ & Third level \\
\hline
\end{tabular}

Type (Faculty type where IS resides): = B=Business, $\mathrm{T}=$ Technology, $\mathrm{O}=$ Other (e.g., Arts), $2=$ Both (has IS groups in $\mathrm{B}$ and $\mathrm{T}$ ), $\mathrm{C}=\mathrm{Combined}$ (has $\mathrm{B}$ and $\mathrm{T}$ in a single faculty). Era: $\mathrm{SS}=$ Sandstone, $\mathrm{RB}=$ Redbrick, GT = Gumtrees, UT = Unitech, NU = New University, PU = Private University.

\begin{tabular}{|c|c|c|c|c|c|c|c|c|c|}
\hline PU & C & $\begin{array}{c}\text { Bond } \\
\text { University }\end{array}$ & $\begin{array}{l}\text { Faculty of } \\
\text { Business, } \\
\text { Tech and } \\
\text { Sustainable } \\
\text { Development }\end{array}$ & $\begin{array}{c}\text { School of } \\
\text { Information } \\
\text { Tech }\end{array}$ & $\begin{array}{l}\text { Information } \\
\text { Systems } \\
\text { Dept }\end{array}$ & & Faculty & School & Dept \\
\hline $\mathrm{NU}$ & C & $\begin{array}{c}\text { Central } \\
\text { Queensland } \\
\text { University }\end{array}$ & $\begin{array}{l}\text { Faculty of } \\
\text { Business } \\
\text { and } \\
\text { Informatics }\end{array}$ & $\begin{array}{c}\text { School of } \\
\text { Information } \\
\text { Systems }\end{array}$ & & & Faculty & School & \\
\hline GT & 2 & $\begin{array}{c}\text { Griffith } \\
\text { University }\end{array}$ & $\begin{array}{c}\text { Business } \\
\text { (group) }\end{array}$ & $\begin{array}{c}\text { Griffith } \\
\text { Business } \\
\text { School }\end{array}$ & $\begin{array}{c}\text { Dept of } \\
\text { Mgmt }\end{array}$ & (IS group) & Group & $\begin{array}{c}\text { School } \\
\text { (only in } \\
\text { Business) } \\
\text { or faculty }\end{array}$ & $\begin{array}{l}\text { Dept (only } \\
\text { in } \\
\text { Business) }\end{array}$ \\
\hline GT & 2 & $\begin{array}{l}\text { Griffith } \\
\text { University }\end{array}$ & $\begin{array}{l}\text { Griffith } \\
\text { Science } \\
\text { and Tech } \\
\text { (group) }\end{array}$ & $\begin{array}{c}\text { Faculty of } \\
\text { Engineering } \\
\text { and } \\
\text { Information } \\
\text { Tech }\end{array}$ & $\begin{array}{c}\text { School of } \\
\text { Information } \\
\text { and Comm } \\
\text { Tech }\end{array}$ & (IS group) & Group & Faculty & School \\
\hline GT & B & $\begin{array}{c}\text { James } \\
\text { Cook } \\
\text { University }\end{array}$ & $\begin{array}{l}\text { Faculty of } \\
\text { Law, } \\
\text { Business } \\
\text { and } \\
\text { Creative } \\
\text { Arts }\end{array}$ & $\begin{array}{l}\text { School of } \\
\text { Business }\end{array}$ & $\begin{array}{c}\text { Accounting } \\
\text { and } \\
\text { Finance } \\
\text { Program }\end{array}$ & (IS group) & Faculty & School & Program \\
\hline UT & $T$ & $\begin{array}{c}\text { Queensland } \\
\text { University } \\
\text { of } \\
\text { Technology }\end{array}$ & $\begin{array}{c}\text { Faculty of } \\
\text { Information } \\
\text { Tech }\end{array}$ & $\begin{array}{c}\text { School of } \\
\text { Information } \\
\text { Systems }\end{array}$ & & & Faculty & School & \\
\hline
\end{tabular}


Table 1.3 Placement of the IS academic discipline in Queensland universities

\begin{tabular}{|c|c|c|c|c|c|c|c|c|c|}
\hline & & & \multicolumn{4}{|c|}{ Location of IS within the university } & \multicolumn{3}{|c|}{ Generic levels } \\
\hline Era & Type & University & $\begin{array}{c}\text { First level } \\
\text { down }\end{array}$ & $\begin{array}{c}\text { Second } \\
\text { level down }\end{array}$ & $\begin{array}{c}\text { Third level } \\
\text { down }\end{array}$ & $\begin{array}{c}\text { Fourth } \\
\text { level down }\end{array}$ & First level & $\begin{array}{c}\text { Second } \\
\text { level }\end{array}$ & Third level \\
\hline SS & 2 & $\begin{array}{l}\text { University } \\
\text { of } \\
\text { Queensland }\end{array}$ & $\begin{array}{l}\text { Faculty of } \\
\text { Engineering, } \\
\text { Physical } \\
\text { Sciences } \\
\text { and } \\
\text { Architecture }\end{array}$ & $\begin{array}{c}\text { School of } \\
\text { Information } \\
\text { Technology } \\
\text { and } \\
\text { Electrical } \\
\text { Engineering }\end{array}$ & \begin{tabular}{|c|} 
Data and \\
Knowledge \\
Engineering \\
Research \\
Division
\end{tabular} & & Faculty & School & $\begin{array}{c}\text { Research } \\
\text { division }\end{array}$ \\
\hline SS & B & $\begin{array}{l}\text { University } \\
\text { of } \\
\text { Queensland }\end{array}$ & $\begin{array}{c}\text { Faculty of } \\
\text { Business, } \\
\text { Economics } \\
\text { and Law }\end{array}$ & $\begin{array}{c}\text { UQ } \\
\text { Business } \\
\text { School }\end{array}$ & (IS group) & & Faculty & School & Discipline \\
\hline NU & $B$ & $\begin{array}{c}\text { University } \\
\text { of } \\
\text { Southern } \\
\text { Queensland }\end{array}$ & $\begin{array}{l}\text { Faculty of } \\
\text { Business }\end{array}$ & $\begin{array}{c}\text { Dept of } \\
\text { Information } \\
\text { Systems }\end{array}$ & & & Faculty & Dept & \\
\hline
\end{tabular}

Vignettes are presented of Ed Fitzgerald, Alan Underwood and Ron Weber, as three of the many individuals who have been important to the development of the IS discipline in Queensland. Fitzgerald can be seen to have been one of the powerful forces in the evolution of IS curriculum in Queensland, with an innovative practitioner-focused approach. Underwood for many years led the largest IS group at a Queensland university and promoted IS strongly through his involvement with the ACS. Weber has been perhaps the most prominent and admired Australian IS academic internationally. The study assesses the state of IS in Queensland universities in relation to criteria indicative of the maturity of a discipline. Measured against these criteria, IS in Queensland universities cannot be considered a mature, distinct academic discipline but emerges, nonetheless, as vigorous and innovative.

\section{The IS discipline in the Australian Capital Territory, 2006}

The ACT case study was prepared by three leaders in IS (Gregor, Lewis and McDonald) from the territory's three universities. The authors briefly discuss Roger Clarke, Igor Hawryszkiewycz, Errol Martin and Penny Collings as individuals who had-as well as the authors - contributed strongly to the development of the IS academic discipline in the Australian Capital Territory. The chapter depicts a vibrant IS group in each university but voices concerns about the disparate administrative locations of the IS academics (Table 1.4) and the relative lack of a strong identity for IS in the territory's universities. 
Table 1.4 Placement of the IS academic discipline in ACT universities

\begin{tabular}{|c|c|c|c|c|c|c|c|c|c|}
\hline & & & \multicolumn{4}{|c|}{ Location of IS within the university } & \multicolumn{3}{|c|}{ Generic levels } \\
\hline Era & Type & University & $\begin{array}{c}\text { First level } \\
\text { down }\end{array}$ & $\begin{array}{c}\text { Second } \\
\text { level down }\end{array}$ & $\begin{array}{c}\text { Third level } \\
\text { down }\end{array}$ & $\begin{array}{c}\text { Fourth } \\
\text { level down }\end{array}$ & First level & $\begin{array}{c}\text { Second } \\
\text { level }\end{array}$ & Third level \\
\hline
\end{tabular}

Type (faculty type where IS resides): $\mathrm{B}=$ Business, $\mathrm{T}=$ Technology, $\mathrm{O}=$ Other (eg., Arts), $2=$ Both (has IS groups in $\mathrm{B}$ and $\mathrm{T}$ ), $\mathrm{C}=\mathrm{Combined}$ (has $\mathrm{B}$ and $\mathrm{T}$ in a single faculty). Era: $\mathrm{SS}=$ Sandstone, $\mathrm{RB}=$ Redbrick, GT = Gumtrees, UT = Unitech, NU = New University, PU = Private University.

\begin{tabular}{c|c|c|c|c|c|c|c|c}
\hline RB & B & $\begin{array}{c}\text { Australian } \\
\text { National } \\
\text { University }\end{array}$ & $\begin{array}{c}\text { College of } \\
\text { Business } \\
\text { and } \\
\text { Economics }\end{array}$ & $\begin{array}{c}\text { School of } \\
\text { Accounting } \\
\text { and } \\
\text { Business } \\
\text { Information } \\
\text { Systems }\end{array}$ & $\begin{array}{c}\text { Information } \\
\text { Systems } \\
\text { Discipline } \\
\text { Group }\end{array}$ \\
NU & $\mathrm{C}$ & $\begin{array}{c}\text { University } \\
\text { of } \\
\text { Canberra }\end{array}$ & $\begin{array}{c}\text { Division of } \\
\text { Business, } \\
\text { Law and } \\
\text { Information } \\
\text { Sciences }\end{array}$ & $\begin{array}{c}\text { School of } \\
\text { Information } \\
\text { Sciences } \\
\text { and } \\
\text { Engineering }\end{array}$ & $\begin{array}{c}\text { Information } \\
\text { Systems } \\
\text { Discipline }\end{array}$ \\
RB & $\mathrm{T}$ & $\begin{array}{c}\text { University } \\
\text { of NSW } \\
\text { (ADFA) }\end{array}$ & $\begin{array}{c}\text { Australian } \\
\text { Defence } \\
\text { Force } \\
\text { Academy }\end{array}$ & $\begin{array}{c}\text { School of } \\
\text { IT and } \\
\text { Electrical } \\
\text { Engineering }\end{array}$ & (IS group) & Division & School & Discipline \\
\hline
\end{tabular}

Information systems is prominent at all three universities, each having a distinctive background that reflects its position in Canberra, the seat of Australia's federal government. The Australian Defence Force Academy (ADFA, University of New South Wales) is essentially a private university for the Australian Defence Organisation; The Australian National University was set up to be a national research institution; and the University of Canberra group for many years focused on meeting the training needs for computing professionals for the federal government. Despite these distinguishing characteristics, the subject matter taught and researched in the three groups has much in common and "each group regards itself as "vibrant" and happy with what it does'. Nonetheless, a low degree of professionalisation is reported relative to longer-standing disciplines, it being suggested that this is to some extent due to the fact that there exists 'a disjunction between what is taught as core knowledge and what is taught as research methods', a lack of social prestige and a lack of acceptance as a discipline with a unique symbol system.

\section{The IS discipline in New South Wales, 2006, and response}

The main NSW chapter, by Underwood and Jordan, identifies 12 separate IS academic groups across nine universities in the state. Unlike in the other state reports, the authors choose to address only a subset of the NSW universities - those they consider the most prominent in IS (some might disagree with their selection). They observe that students undertaking strongly identified IS undergraduate degrees can be found at few universities, with most offering a variety of majors within other programs. The size of the IS presence would therefore appear to depend on the university's enrolment in the core programs that offer the majors and the extent of compulsory IS subjects in their programs. Large accounting programs mean that many students will need to do IS, thereby 
requiring larger IS staff numbers. Growing enrolments in commerce during two decades has advantaged IS units and staff in that faculty. Nonetheless, IS would appear not to have a common home, but resides in a variety of locations - especially science and computer science-as shown in Table 1.5. Most IS groups remain as ad hoc or informal groups within larger departments.

\section{Table 1.5 Placement of the IS academic discipline in NSW universities}

\begin{tabular}{|c|c|c|c|c|c|c|c|c|c|}
\hline & & & \multicolumn{4}{|c|}{ Location of IS within the university } & \multicolumn{3}{|c|}{ Generic levels } \\
\hline Era & Type & University & $\begin{array}{c}\text { First level } \\
\text { down }\end{array}$ & $\begin{array}{c}\text { Second } \\
\text { level down }\end{array}$ & \begin{tabular}{|c|}
$\begin{array}{c}\text { Third level } \\
\text { down }\end{array}$ \\
\end{tabular} & $\begin{array}{c}\text { Fourth } \\
\text { level down }\end{array}$ & First level & $\begin{array}{c}\text { Second } \\
\text { level }\end{array}$ & Third level \\
\hline \multicolumn{10}{|c|}{$\begin{array}{c}\text { Type (faculty type where IS resides): } \mathrm{B}=\text { Business, } \mathrm{T}=\text { Technology, } \mathrm{O}=\mathrm{O} \text { - } \mathrm{\text {ther }} \text { (eg., Arts), } 2=\text { Both (has IS } \\
\text { groups in } \mathrm{B} \text { and } \mathrm{T} \text { ), } \mathrm{C}=\text { Combined (has } \mathrm{B} \text { and } \mathrm{T} \text { in a single faculty). Era: } \mathrm{SS}=\text { Sandstone, } \mathrm{RB}=\text { Redbrick, } \\
\mathrm{GT}=\text { Gumtrees, UT = Unitech, NU = New University, } \mathrm{PU}=\text { Private University. }\end{array}$} \\
\hline $\mathrm{NU}$ & C & \begin{tabular}{|c|} 
Charles \\
Sturt \\
University \\
(Albury) \\
from 2007
\end{tabular} & \begin{tabular}{|c|} 
Faculty of \\
Business \\
and \\
Computing
\end{tabular} & \begin{tabular}{|c|} 
School of \\
Business \\
and \\
Information \\
Tech
\end{tabular} & (IS group) & & & & \\
\hline $\mathrm{NU}$ & $\mathrm{C}$ & $\begin{array}{c}\text { Charles } \\
\text { Sturt } \\
\text { University } \\
\text { (Wagga } \\
\text { Wagga) } \\
\text { from 2007 }\end{array}$ & $\begin{array}{c}\text { Faculty of } \\
\text { Business } \\
\text { and } \\
\text { Computing } \\
\text { (proposed } \\
\text { name) }\end{array}$ & \begin{tabular}{|c|} 
School of \\
Computing \\
and \\
Mathematics \\
(proposed \\
name)
\end{tabular} & (IS group) & & Faculty & School & \\
\hline GT & 2 & $\begin{array}{l}\text { Macquarie } \\
\text { University }\end{array}$ & $\begin{array}{l}\text { College of } \\
\text { Science } \\
\text { and Tech }\end{array}$ & \begin{tabular}{|c|} 
Division of \\
Information \\
and Comm \\
Sciences
\end{tabular} & $\begin{array}{c}\text { Dept of } \\
\text { Computing }\end{array}$ & (IS group) & College & Division & Dept \\
\hline GT & 2 & $\begin{array}{l}\text { Macquarie } \\
\text { University }\end{array}$ & $\begin{array}{l}\text { College of } \\
\text { Commerce }\end{array}$ & $\begin{array}{c}\text { Division of } \\
\text { Economics } \\
\text { and } \\
\text { Financial } \\
\text { Studies }\end{array}$ & \begin{tabular}{|c|} 
Dept of \\
Accounting \\
and \\
Finance \\
\end{tabular} & (IS group) & College & Division & Dept \\
\hline GT & 2 & $\begin{array}{l}\text { Macquarie } \\
\text { University }\end{array}$ & $\begin{array}{l}\text { College of } \\
\text { Commerce }\end{array}$ & $\begin{array}{c}\text { Macquarie } \\
\text { Graduate } \\
\text { School of } \\
\text { Mgmt }\end{array}$ & (IS) & & College & Division & Dept \\
\hline NU & $B$ & $\begin{array}{l}\text { Southern } \\
\text { Cross } \\
\text { University }\end{array}$ & $\begin{array}{l}\text { Faculty of } \\
\text { Business }\end{array}$ & $\begin{array}{l}\text { School of } \\
\text { Commerce } \\
\text { and Mgmt }\end{array}$ & (IS group) & & Faculty & School & \\
\hline GT & $B$ & $\begin{array}{l}\text { University } \\
\text { of New } \\
\text { England }\end{array}$ & $\begin{array}{l}\text { Faculty of } \\
\text { Economics, } \\
\text { Business } \\
\text { and Law }\end{array}$ & $\begin{array}{c}\text { New } \\
\text { England } \\
\text { Business } \\
\text { School }\end{array}$ & (IS) & & Faculty & School & \\
\hline GT & $\mathrm{T}$ & $\begin{array}{l}\text { University } \\
\text { of } \\
\text { Newcastle }\end{array}$ & \begin{tabular}{|c|} 
Faculty of \\
Science \\
and \\
Information \\
Tech
\end{tabular} & \begin{tabular}{|c|} 
School of \\
Design \\
Comm \\
Information \\
Tech
\end{tabular} & \begin{tabular}{|c|} 
Information \\
Tech \\
Discipline
\end{tabular} & (IS group) & Faculty & School & Discipline \\
\hline $\mathrm{RB}$ & $B$ & $\begin{array}{c}\text { University } \\
\text { of NSW }\end{array}$ & $\begin{array}{c}\text { Faculty of } \\
\text { Commerce } \\
\text { and } \\
\text { Economics }\end{array}$ & $\begin{array}{c}\text { School of } \\
\text { Information } \\
\text { Systems, } \\
\text { Tech and } \\
\text { Mgmt }\end{array}$ & (IS group) & & Faculty & School & \\
\hline
\end{tabular}


Table 1.5 Placement of the IS academic discipline in NSW universities

\begin{tabular}{|c|c|c|c|c|c|c|c|c|c|}
\hline & & & \multicolumn{4}{|c|}{ Location of IS within the university } & \multicolumn{3}{|c|}{ Generic levels } \\
\hline Era & Type & University & $\begin{array}{c}\text { First level } \\
\text { down }\end{array}$ & $\begin{array}{c}\text { Second } \\
\text { level down }\end{array}$ & $\begin{array}{c}\text { Third level } \\
\text { down }\end{array}$ & $\begin{array}{c}\text { Fourth } \\
\text { level down }\end{array}$ & First level & $\begin{array}{c}\text { Second } \\
\text { level }\end{array}$ & Third level \\
\hline SS & 2 & $\begin{array}{l}\text { University } \\
\text { of Sydney }\end{array}$ & $\begin{array}{l}\text { Faculty of } \\
\text { Science }\end{array}$ & \begin{tabular}{|c|} 
School of \\
Information \\
Technologies
\end{tabular} & (IS group) & & & & \\
\hline SS & 2 & $\begin{array}{l}\text { University } \\
\text { of Sydney }\end{array}$ & $\begin{array}{c}\text { Faculty of } \\
\text { Economics } \\
\text { and } \\
\text { Business }\end{array}$ & $\begin{array}{l}\text { School of } \\
\text { Business }\end{array}$ & \begin{tabular}{|c|} 
Discipline \\
of \\
Business \\
Information \\
Systems
\end{tabular} & & Faculty & School & Discipline \\
\hline UT & $\mathrm{T}$ & $\begin{array}{l}\text { University } \\
\text { of } \\
\text { Technology, } \\
\text { Sydney }\end{array}$ & $\begin{array}{c}\text { Faculty of } \\
\text { Information } \\
\text { Tech }\end{array}$ & $\begin{array}{c}\text { Dept of } \\
\text { Information } \\
\text { Systems }\end{array}$ & & & Faculty & $\begin{array}{c}\text { School } \\
\text { (only in } \\
\text { the } \\
\text { Business } \\
\text { Faculty) or } \\
\text { dept }\end{array}$ & \\
\hline NU & 2 & $\begin{array}{l}\text { University } \\
\text { of Western } \\
\text { Sydney } \\
\text { (E-Business) }\end{array}$ & $\begin{array}{c}\text { College of } \\
\text { Business }\end{array}$ & $\begin{array}{c}\text { School of } \\
\text { Mgmt }\end{array}$ & $\begin{array}{c}\text { Business } \\
\text { Systems } \\
\text { Group }\end{array}$ & & College & School & \\
\hline NU & 2 & $\begin{array}{l}\text { University } \\
\text { of Western } \\
\text { Sydney } \\
\text { (IS) }\end{array}$ & $\begin{array}{l}\text { College of } \\
\text { Health and } \\
\text { Science }\end{array}$ & $\begin{array}{c}\text { School of } \\
\text { Computing } \\
\text { and } \\
\text { Mathematics }\end{array}$ & (IS group) & & College & School & \\
\hline GT & $B$ & $\begin{array}{c}\text { University } \\
\text { of } \\
\text { Wollongong }\end{array}$ & $\begin{array}{l}\text { Faculty of } \\
\text { Commerce }\end{array}$ & $\begin{array}{c}\text { School of } \\
\text { Economics } \\
\text { and } \\
\text { Information } \\
\text { Systems }\end{array}$ & $\begin{array}{c}\text { Discipline } \\
\text { of } \\
\text { Information } \\
\text { Systems }\end{array}$ & & Faculty & School & \\
\hline
\end{tabular}

The NSW chapter includes vignettes from Dubravka Cecez-Kecmanovic and Igor Hawryszkiewycz. Cecez-Kecmanovic has made a significant contribution to IS research through her effective promotion of critical theory-informed IS research. Hawryszkiewycz has had a long-term impact on IS curriculum and research and has authored IS textbooks important to the development of IS in Australia. While the universities reported by Underwood and Jordan display some structural recognition of IS as a separate field, it was widely believed by their interviewees that the distinctiveness of IS was not well known in the wider university communities. Indeed, the interviewees themselves appeared to hold diverse definitions of IS. Research activity tends to be fragmented and diverse. Small research groups, especially of doctoral students, have tended to exist without undergraduate programs to build the staff numbers to critical mass.

Wilson provides a response to the conclusions developed by Underwood and Jordan. While Underwood and Jordan conclude that the prospects for IS in most NSW universities are poor - they speak of 'an environment threatening the continuing existence of IS in some of the state's universities' - Wilson argues for a much more positive future. Wilson's arguments are that New South Wales has by far the largest information and communications technology (ICT) presence in Australia and that the greatest demand among ICT graduates is for those with 'a business-centric focus' - that is, IS graduates. 


\section{IS in South Australia: a critical investigation}

The South Australian chapter emphasises the leading role of the University of South Australia. Data gathered suggest that South Australia's IS offerings were influenced heavily during the 1990s by the soft systems and critical systems approaches to the discipline - a situation that began to change at the turn of the century - and that the curriculum depended more heavily on industrial than on political factors. Though the authors report several substantive research centres or labs, it is also noted that there is little local funding for research, and while the three universities work together fairly well and have created some highly successful technical joint ventures, with IS playing such a minor role in the state, obtaining funding for any research activities is extremely difficult. The administrative placement of IS in South Australian universities is shown in Table 1.6.

Table 1.6 Placement of the IS academic discipline in SA universities

\begin{tabular}{|c|c|c|c|c|c|c|c|c|c|}
\hline & & & \multicolumn{4}{|c|}{ Location of IS within the university } & \multicolumn{3}{|c|}{ Generic levels } \\
\hline Era & Type & University & $\begin{array}{c}\text { First level } \\
\text { down }\end{array}$ & $\begin{array}{c}\text { Second } \\
\text { level down }\end{array}$ & \begin{tabular}{|c|}
$\begin{array}{c}\text { Third level } \\
\text { down }\end{array}$ \\
\end{tabular} & $\begin{array}{c}\text { Fourth } \\
\text { level down }\end{array}$ & First level & $\begin{array}{c}\text { Second } \\
\text { level }\end{array}$ & Third level \\
\hline \multicolumn{10}{|c|}{$\begin{array}{l}\text { Type (faculty type where IS resides): } B=\text { Business, } T=\text { Technology, } O=\text { Other (eg., Arts), } 2=\text { Both (has IS } \\
\text { groups in } B \text { and T), } C=\text { Combined (has B and } T \text { in a single faculty). Era: } S S=\text { Sandstone, } R B=\text { Redbrick, } \\
\text { GT = Gumtrees, UT = Unitech, NU = New University, PU = Private University. }\end{array}$} \\
\hline GT & $\mathrm{T}$ & \begin{tabular}{|c|} 
Flinders \\
University
\end{tabular} & $\begin{array}{l}\text { Faculty of } \\
\text { Science } \\
\text { and } \\
\text { Engineering }\end{array}$ & $\begin{array}{c}\text { School of } \\
\text { Informatics } \\
\text { and } \\
\text { Engineering }\end{array}$ & (IS group) & & Faculty & $\begin{array}{c}\text { School or } \\
\text { dept }\end{array}$ & \\
\hline SS & B & $\begin{array}{l}\text { University } \\
\text { of } \\
\text { Adelaide }\end{array}$ & $\begin{array}{l}\text { Faculty of } \\
\text { the } \\
\text { Professions }\end{array}$ & $\begin{array}{c}\text { School of } \\
\text { Commerce }\end{array}$ & $\begin{array}{l}\text { (IS group) } \\
3 \text { staff }\end{array}$ & & Faculty & School & \\
\hline UT & $\mathrm{T}$ & $\begin{array}{l}\text { University } \\
\text { of South } \\
\text { Australia }\end{array}$ & $\begin{array}{l}\text { Division of } \\
\text { Information } \\
\text { Tech, } \\
\text { Engineering } \\
\text { and the } \\
\text { Environment }\end{array}$ & \begin{tabular}{|c|} 
School of \\
Computer \\
and \\
Information \\
Science
\end{tabular} & (IS group) & & Division & School & \\
\hline
\end{tabular}

A vignette is provided from Terry Robbins-Jones, head of the first School of Information Systems in South Australia and innovative leader in the promotion of IS.

\section{The IS discipline in Tasmania, 2006}

The Tasmanian case study is distinctive in several respects. First, it reports on just one university. Also, the data-gathering approach applied is somewhat different. Where reports in the other states used interviews from one or two senior academics in each university, in Tasmania it was possible to draw on data from a wide range of academics - current and former staff members from the University of Tasmania. The chapter includes vignettes from Chris Keen, a man who had a formative impact on the development of the IS discipline in Tasmania, and Arthur Sale, one of the father figures of ICT in Australia and a major proponent of IS at the University of Tasmania. The author of the Tasmanian report is also the author of the framework developed for the overall case-study 
protocol. The administrative placement of IS at the University of Tasmania is shown in Table 1.7.

Table 1.7 Placement of the IS academic discipline in the University of Tasmania

\begin{tabular}{|c|c|c|c|c|c|c|c|c|c|}
\hline & & & \multicolumn{4}{|c|}{ Location of IS within the university } & \multicolumn{3}{|c|}{ Generic levels } \\
\hline Era & Type & University & $\begin{array}{l}\text { First level } \\
\text { down }\end{array}$ & $\begin{array}{c}\text { Second } \\
\text { level down }\end{array}$ & $\begin{array}{c}\text { Third level } \\
\text { down }\end{array}$ & $\begin{array}{c}\text { Fourth } \\
\text { level down }\end{array}$ & First level & $\begin{array}{c}\text { Second } \\
\text { level }\end{array}$ & Third level \\
\hline \multicolumn{10}{|c|}{$\begin{array}{c}\text { Type (faculty type where IS resides): } \mathrm{B}=\text { Business, } \mathrm{T}=\text { Technology, } \mathrm{O}=\text { Other (eg., Arts), } 2=\text { Both (has IS } \\
\text { groups in } \mathrm{B} \text { and T), } \mathrm{C}=\text { Combined (has B and } \mathrm{T} \text { in a single faculty). Era: } \mathrm{SS}=\text { Sandstone, RB = Redbrick, } \\
\text { GT = Gumtrees, UT = Unitech, NU = New University, PU = Private University. }\end{array}$} \\
\hline SS & $B$ & $\begin{array}{l}\text { University } \\
\quad \text { of } \\
\text { Tasmania }\end{array}$ & $\begin{array}{l}\text { Faculty of } \\
\text { Business }\end{array}$ & $\begin{array}{c}\text { School of } \\
\text { Information } \\
\text { Systems }\end{array}$ & & & Faculty & School & \\
\hline
\end{tabular}

The Tasmanian case-study findings suggest that an inverse relationship exists between the impact of local factors and the degree of professionalism in this IS setting. A surprising finding was that the relationship found varied for research and teaching issues.

\section{The IS discipline in Victoria, 2006}

Victoria - more than any other state - was impacted heavily by the Dawkins reforms to Australian tertiary education. Amalgamations, mergers and take-overs were widespread in Victoria, sometimes bringing together strong IS groups with different cultures and different aspirations. Although most interviewees expressed the view that local industry had had negligible influence on curriculum, universities in Victoria appeared to be universally seeking increased collaboration with the local community and industry as part of their strategic direction. Distinctive themes taught within the many programs identified varied considerably. Despite diverse topics of research being pursued, IS research output in universities in Victoria was perceived as lesser than in other departments. Efforts are, however, under way to bolster research output. Interestingly, the Victorian report states, 'The mode of IS research in universities in Victoria is predominantly interpretive.' Only one university reported using 'multi-method, with an emphasis on quantitative techniques'. Although research is considered a high priority at almost all universities in Victoria, available funding appears to have a negative correlation with the avowed importance of research. Perceptions of 'very little funding', 'dwindling funding' and 'having trouble attracting ARC [Australian Research Council] and other external funding' were evident in the data. A diversity of administrative placements for IS groups in Victorian universities is shown in Table 1.8. 
Table 1.8 Placement of the IS academic discipline in Victorian universities

\begin{tabular}{|c|c|c|c|c|c|c|c|c|c|}
\hline \multirow[b]{2}{*}{ Era } & \multirow[b]{2}{*}{ Type } & \multirow[b]{2}{*}{ University } & \multicolumn{4}{|c|}{ Location of IS within the university } & \multicolumn{3}{|c|}{ Generic levels } \\
\hline & & & $\begin{array}{c}\text { First level } \\
\text { down }\end{array}$ & $\begin{array}{c}\text { Second } \\
\text { level down }\end{array}$ & $\begin{array}{c}\text { Third level } \\
\text { down }\end{array}$ & \begin{tabular}{|c|} 
Fourth \\
level down
\end{tabular} & First level & $\begin{array}{c}\text { Second } \\
\text { level }\end{array}$ & Third level \\
\hline \multicolumn{10}{|c|}{$\begin{array}{c}\text { Type (faculty type where IS resides): } B=\text { Business, } T=\text { Technology, } O=\text { Other (eg., Arts), } 2=\text { Both (has IS } \\
\text { groups in } B \text { and T), } C=\text { Combined (has B and } T \text { in a single faculty). Era: } S S=\text { Sandstone, RB = Redbrick, } \\
\text { GT = Gumtrees, UT = Unitech, NU = New University, PU = Private University. }\end{array}$} \\
\hline GT & B & \begin{tabular}{|c|} 
Deakin \\
University
\end{tabular} & $\begin{array}{l}\text { Faculty of } \\
\text { Business } \\
\text { and Law }\end{array}$ & $\begin{array}{l}\text { School of } \\
\text { Information } \\
\text { Systems }\end{array}$ & & & Faculty & School & \\
\hline GT & B & $\begin{array}{c}\text { Deakin } \\
\text { University }\end{array}$ & $\begin{array}{l}\text { Faculty of } \\
\text { Business } \\
\text { and Law }\end{array}$ & $\begin{array}{l}\text { Deakin } \\
\text { Business } \\
\text { School }\end{array}$ & \begin{tabular}{|} 
Information \\
Systems \\
Discipline \\
Group (3 \\
staff)
\end{tabular} & & Faculty & School & \\
\hline GT & $\mathrm{T}$ & $\begin{array}{l}\text { La Trobe } \\
\text { University }\end{array}$ & $\begin{array}{c}\text { Faculty of } \\
\text { Science, } \\
\text { Tech and } \\
\text { Engineering }\end{array}$ & $\begin{array}{c}\text { School of } \\
\text { Engineering } \\
\text { and } \\
\text { Mathematical } \\
\text { Sciences }\end{array}$ & \begin{tabular}{|c|} 
Dept of \\
Computer \\
Science \\
and \\
Computer \\
Engineering
\end{tabular} & (IS group) & Faculty & School & Dept \\
\hline $\mathrm{RB}$ & $\mathrm{T}$ & $\begin{array}{c}\text { Monash } \\
\text { University }\end{array}$ & \begin{tabular}{|c|} 
Faculty of \\
Information \\
Tech
\end{tabular} & $\begin{array}{c}\text { Caulfield } \\
\text { School of } \\
\text { Information } \\
\text { Tech }\end{array}$ & (IS group) & & Faculty & School & \\
\hline $\mathrm{RB}$ & $\mathrm{T}$ & $\begin{array}{c}\text { Monash } \\
\text { University }\end{array}$ & $\begin{array}{c}\text { Faculty of } \\
\text { Information } \\
\text { Tech }\end{array}$ & $\begin{array}{c}\text { Clayton } \\
\text { School of } \\
\text { Information } \\
\text { Tech }\end{array}$ & (IS group) & & Faculty & School & \\
\hline UT & $\mathrm{B}$ & $\begin{array}{c}\text { RMIT } \\
\text { University }\end{array}$ & $\begin{array}{l}\text { Faculty of } \\
\text { Business }\end{array}$ & $\begin{array}{l}\text { School of } \\
\text { Business } \\
\text { IT }\end{array}$ & & & Faculty & School & \\
\hline $\mathrm{NU}$ & $\mathrm{T}$ & $\begin{array}{c}\text { Swinburne } \\
\text { University } \\
\text { of } \\
\text { Technology }\end{array}$ & \begin{tabular}{|l|} 
Faculty of \\
Information \\
and Comm \\
Technologies
\end{tabular} & $\begin{array}{c}\text { Information } \\
\text { Systems } \\
\text { Academic } \\
\text { Group }\end{array}$ & & & Faculty & $\begin{array}{c}\text { Academic } \\
\text { group }\end{array}$ & \\
\hline NU & $\mathrm{T}$ & $\begin{array}{l}\text { University } \\
\text { of Ballarat }\end{array}$ & \begin{tabular}{|c|} 
School of \\
Information \\
Tech and \\
Mathematical \\
Sciences
\end{tabular} & (IS group) & & & School & & \\
\hline SS & $\mathrm{T}$ & $\begin{array}{c}\text { University } \\
\text { of } \\
\text { Melbourne }\end{array}$ & $\begin{array}{l}\text { Faculty of } \\
\text { Science }\end{array}$ & $\begin{array}{c}\text { Dept of } \\
\text { Information } \\
\text { Systems }\end{array}$ & & & Faculty & $\begin{array}{c}\text { School or } \\
\text { dept }\end{array}$ & \\
\hline NU & B & $\begin{array}{c}\text { Victoria } \\
\text { University }\end{array}$ & $\begin{array}{l}\text { Faculty of } \\
\text { Business } \\
\text { and Law }\end{array}$ & $\begin{array}{c}\text { School of } \\
\text { Information } \\
\text { Systems }\end{array}$ & & & Faculty & School & \\
\hline
\end{tabular}

The Victorian chapter presents vignettes from two individuals as representatives of many important figures in the development of IS in Victoria. The two are Graeme Shanks, a significant contributor to IS research and early representative on the ARC College of Experts, and Gerald Murphy, 'one of the founding fathers of Australia's IT education sector'.

\section{IS teaching and research in WA universities}

The West Australian chapter identifies a degree of isolation, attributable to the size of the state and its relative remoteness from the universities elsewhere in Australia. The report suggests how these factors have impinged on the development of IS in the state's universities and how responses to local 
contingencies inhibit the perception of IS as a mature discipline. Research focus within the four universities is very different and this could be one of the reasons why all interviewees identified a low level of collaboration between WA universities. Interviewees stressed the real need for IS leadership and active involvement in IS research by the professoriate. Information systems groups without a professor tended to have a significantly lower profile in their home university than those with a professor. Administrative placement of the IS groups is shown in Table 1.9.

Table 1.9 Placement of the IS academic discipline in WA universities

\begin{tabular}{c|c|c|c|c|c|c|c|c|c}
\hline & & & \multicolumn{3}{|c|}{ Location of IS within the university } & \multicolumn{3}{|c}{ Generic levels } \\
\hline Era & Type & University & $\begin{array}{c}\text { First level } \\
\text { down }\end{array}$ & $\begin{array}{c}\text { Second } \\
\text { level down }\end{array}$ & $\begin{array}{c}\text { Third level } \\
\text { down }\end{array}$ & $\begin{array}{c}\text { Fourth } \\
\text { level down }\end{array}$ & First level & $\begin{array}{c}\text { Second } \\
\text { level }\end{array}$ & Third level \\
\hline
\end{tabular}

Type (faculty type where IS resides): $\mathrm{B}=$ Business, $\mathrm{T}=$ Technology, $\mathrm{O}=$ Other (eg., Arts), $2=$ Both (has IS groups in $B$ and $T$ ),$C=$ Combined (has $B$ and $T$ in a single faculty). Era: $S S=$ Sandstone, $R B=$ Redbrick, $\mathrm{GT}=$ Gumtrees, UT = Unitech, NU = New University, PU = Private University.

\begin{tabular}{|c|c|c|c|c|c|c|c|c|c|}
\hline UT & B & $\begin{array}{c}\text { Curtin } \\
\text { University } \\
\text { of } \\
\text { Technology }\end{array}$ & $\begin{array}{l}\text { Curtin } \\
\text { Business } \\
\text { School }\end{array}$ & $\begin{array}{c}\text { School of } \\
\text { Information } \\
\text { Systems }\end{array}$ & & & Division & School & \\
\hline $\mathrm{NU}$ & B & $\begin{array}{c}\text { Edith } \\
\text { Cowan } \\
\text { University }\end{array}$ & $\begin{array}{l}\text { Faculty of } \\
\text { Business } \\
\text { and Law }\end{array}$ & $\begin{array}{c}\text { School of } \\
\text { Information } \\
\text { Systems }\end{array}$ & & & Faculty & School & \\
\hline GT & 0 & $\begin{array}{l}\text { Murdoch } \\
\text { University }\end{array}$ & $\begin{array}{c}\text { Division of } \\
\text { Arts }\end{array}$ & $\begin{array}{c}\text { School of } \\
\text { Information } \\
\text { Tech }\end{array}$ & (IS group) & & Division & School & \\
\hline PU & B & $\begin{array}{c}\text { University } \\
\text { of Notre } \\
\text { Dame }\end{array}$ & $\begin{array}{c}\text { College of } \\
\text { Business }\end{array}$ & $\begin{array}{l}\text { School of } \\
\text { Business }\end{array}$ & (IS) & & College & School & \\
\hline SS & B & $\begin{array}{c}\text { University } \\
\text { of Western } \\
\text { Australia }\end{array}$ & $\begin{array}{l}\text { Faculty of } \\
\text { Economics } \\
\text { and } \\
\text { Commerce }\end{array}$ & $\begin{array}{c}\text { Business } \\
\text { School }\end{array}$ & $\begin{array}{l}\text { Information } \\
\text { Mgmt } \\
\text { Discipline }\end{array}$ & (IS group) & Faculty & School & Discipline \\
\hline
\end{tabular}

The chapter discusses briefly the roles of Richard Watson, Graham Pervan and Janice Burn as three major contributors to the development of IS in WA universities.

\section{A longitudinal study of IS research in Australia}

As part of a study to investigate the state of IS research in Australia, surveys of the heads of all IS discipline groups in Australian universities were conducted in 2004, 2005 and 2006. This chapter relates to the findings of the 2006 survey. The study revealed a wide range of topics researched (with rapid growth in electronic commerce and knowledge management), a range of foci, a balance between positivist and interpretive research; that surveys were the most frequently used research method, and that most research was directed towards informing IS professionals. 


\section{The IS academic discipline in Australian universities: a meta-analysis}

This chapter provides a consolidation and broad interpretation of the data from the sub-studies described in the earlier chapters. The analysis identifies the recent and current positions of the IS discipline in Australian universities. It uses the revised Ridley framework to guide analysis of the consolidated data from each of the sub-studies, in particular from the case studies from each state.

At a basic level, it is worth noting from this chapter that not all universities across Australia have an IS presence. It is in Western Australia, South Australia and New South Wales that universities are found that do not have a definable IS academic group. Victoria was notable as the state with by far the strongest IS presence in its universities; Queensland has a strong IS presence relative to its population. Universities across Australia reported declines in student enrolments and in IS academic staff numbers.

A diversity of research methods and standards is seen in IS groups across Australian universities. Similarly, there is much variety in teaching curricula for IS courses in Australia. This is most evident in the variability of the relative emphasis on 'technical' content among universities; however, the variability does not appear to be based on state-to-state differences.

In relation to the criteria used to evaluate the relative maturity of IS as a discipline, the consolidated data suggest that IS is yet to achieve full maturity. Some of the qualities observed, however, relating to local variability and innovative curriculum, could be viewed as healthy, although they are at odds with the maturity criteria.

The consolidated data show a higher proportion of IS groups administratively separate from business faculties than would be the case in the United States, for instance. The data suggest, however, some slight trend for IS groups in Australian universities to move back to administrative placement within business.

Beyond the assessment of observed data against the proposed framework, this meta-analysis seeks to draw from the Australian data some observations on trends and unresolved tensions, with an emphasis on national and international factors impacting on the status of IS in Australian universities. Among factors discerned was a growing impact on IS groups as a consequence of the proposed introduction of the Research Quality Framework (RQF). The proposed RQF was seen to be affecting, in particular, preferences for research outlets and staffing patterns. Other influences are discussed in the meta-analysis chapter.

\section{The Australasian Conference on Information Systems}

The Australasian Conference on Information Systems (ACIS) ran for its eighteenth consecutive year in December 2007 in Toowoomba. The first conference was 
held at Monash University in 1990 with the name 'First Annual Conference on Information Systems'. In 1991, it was called the 'Second Annual Conference on Information Systems and Database Special Interest Group'. In 1992, it became the 'Australian Conference on Information Systems' and, in 1994, in recognition of the substantive involvement of New Zealand, the name was changed to the 'Australasian Conference on Information Systems'. Until the advent of the Pacific Asia Conference on Information Systems (PACIS) in 1993, ACIS was the only substantial IS conference in the region. Since 1993, ACIS and PACIS have coexisted happily, attracting a large overlap in delegates.

Attendance has stabilised at about 250 people during the past three years; paper submissions at about 250 and paper acceptances about 100 (50 per cent acceptance). Though a less international conference than PACIS, ACIS tends to attract papers and delegates from more than a dozen countries each year (the majority of the papers from Australia and New Zealand).

The first ACIS doctoral consortium on record was in 1995 at Curtin University of Technology. The consortiums began to run regularly from 2001. In 2005, the consortium was extended from one to one-and-a-half days. A doctoral thesis prize from the ACPHIS was introduced in 2004 and is now awarded each year at ACIS.

The conference organisation structure has evolved over time. Until the end of 1994, an interim committee ran the conference. The members of the interim committee were: Roger Clarke (The Australian National University), Igor Hawryszkiewycz (University of Technology, Sydney), Ross Jeffery (University of New South Wales), Ron Weber (University of Queensland) and Peter Weill (University of Melbourne). The decision to finally anoint a rolling ICIS-style ACIS committee and disband the interim committee was made at the end of 1994.

Table 1.10 summarises key characteristics of ACIS over time. Although these data have been vetted carefully by several knowledgeable individuals - including all who reviewed this chapter - it must be acknowledged that the data were compiled from multiple and diverse sources across which inconsistencies were observed. For example, conference dates were expressed differently in some materials depending on what was being included: in 1995, the doctoral consortium was held on 26 September, but papers were really presented on 27-29 September. The Proceedings show the dates for the conference as 26-29 September. In other years, the doctoral consortium dates might be included in some places and excluded in others. The terms 'organising chair', 'conference chair' and 'executive chair' seem to be used inconsistently, even for a single conference. There were differences in the counts of papers for some conferences on different pages of the proceedings, and the counts given did not always correspond to the real number of papers in the proceedings (though they were always very close). 
The information systems discipline in Australian universities: a contextual framework

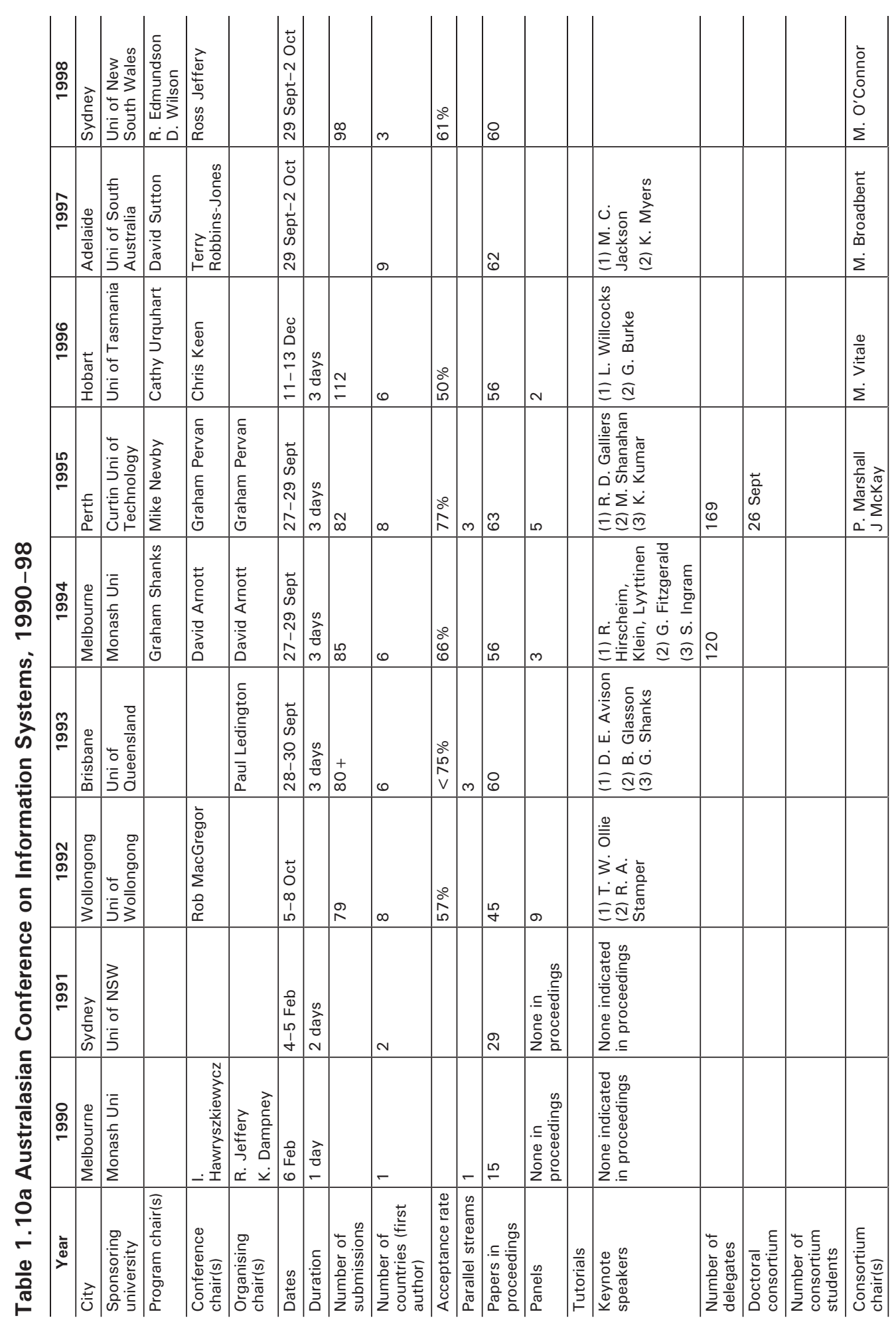


The Information Systems Academic Discipline in Australia

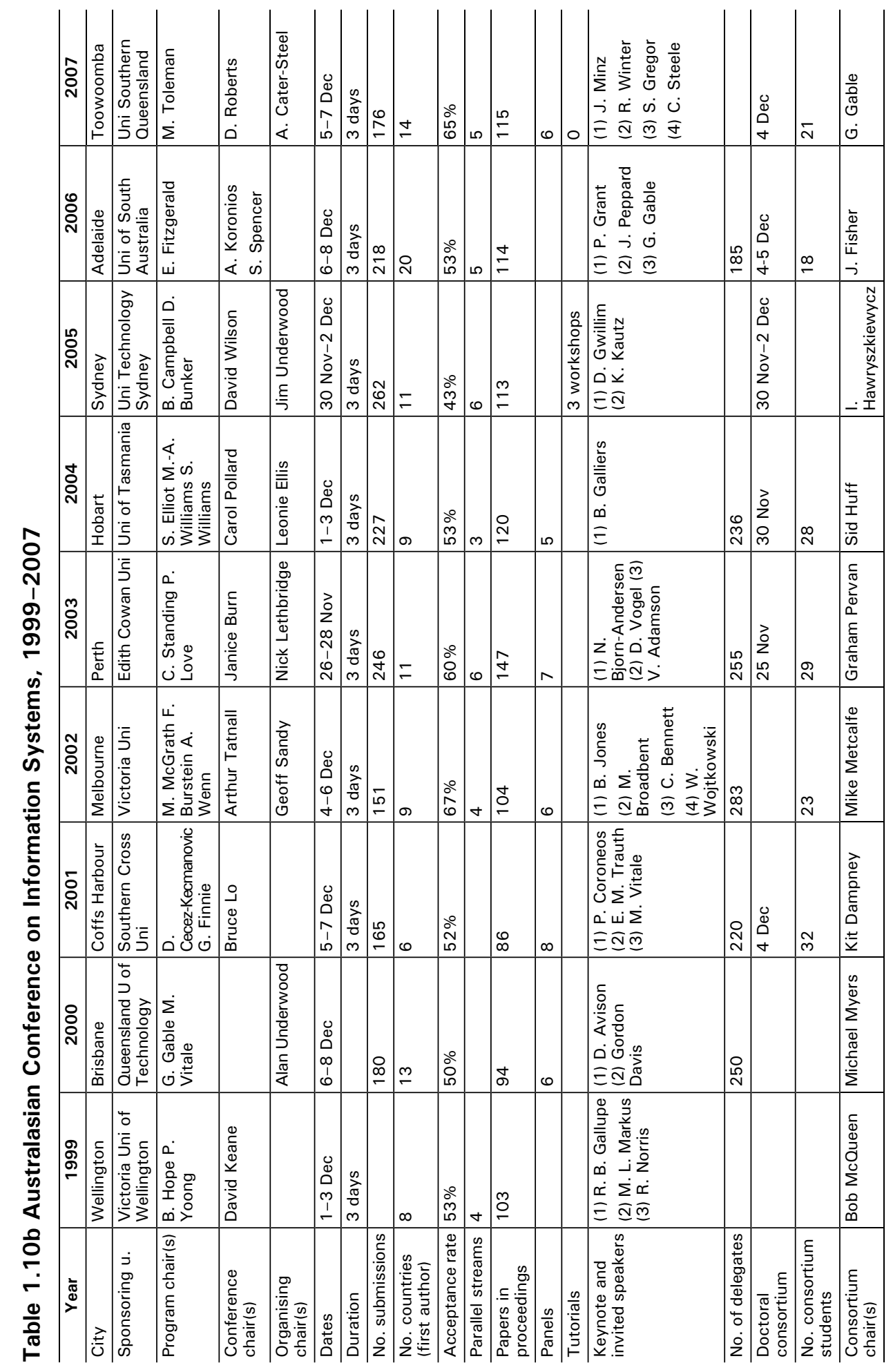




\section{ACIS archival analysis}

A study of ACIS proceedings during its 18-year history has the potential to reveal a good deal about research in Australian (and New Zealand) universities. To this end, the author of this chapter has initiated an archival analysis of ACIS proceedings. To date, the papers from the first 16 ACIS events have been converted to electronic format and salient data from each of the papers have been captured in an EndNote database. A database that is more conducive to data analysis is being built.

Though analyses of the ACIS archival material are in progress, we are able to report some preliminary findings. Counts reported here were done using 'Search References' in EndNote and are for the years 1990-2005. More reliable counts will be available once the data are loaded into the intended database.

All papers have been classified using the classification options:

- technical

- behavioural/managerial

- educational (that is, IS curriculum related)

- other (predominantly research methodology papers).

The papers have also been coded according to topic. This coding is preliminary, and it is our intention that the codes be confirmed by the authors of papers. A 32-topic coding scheme was used based on Barki et al. (1993) and Palvia et al. (2004). The choice of the coding scheme was intended to facilitate the comparison of topics covered at ACIS with those covered in IS research topic studies elsewhere.

In the years 1990-95, about 30 per cent of the papers were classified as technical while in the years $2000-05$ only 12 per cent were classified this way. In the years 2000-05, the percentage of papers that were coded as 'organisational environment' or 'external environment' was approximately double that of the years 1990-95. These changes support the premise that research in IS has been moving away from a more technical emphasis in the early years and is now placing more importance on context.

There has been no real pattern to the inclusion of curriculum-related topics. Most commonly, 7-8 per cent of papers are curriculum related. The first five years of the conference include the years with the highest and the lowest percentages of such papers. At the First Annual Conference on Information Systems, three of the 15 papers (20 per cent) were curriculum related; in 1994, there were no curriculum-related papers.

As new technologies have developed, new topics have emerged, interest in other topics has fallen away and previously discussed topics have taken on a new focus. For example, in recent years research into electronic 
commerce/inter-organisational systems has peaked, research interest in databases/DBMS has waned somewhat and there are new stirrings of interest in hardware due mainly to research into mobile devices such as PDAs.

The most popular topics have been:

- IS development/methods and tools: 14 per cent

- theory of IS: 9 per cent

- electronic commerce/inter-organisational systems: 6 per cent

- resource management/IS management issues: 6 per cent

- IS education: 5 per cent

- IS application areas: 5 per cent.

The universities that have contributed most papers (as of 2005) are:

- Monash University: 8.3 per cent

- University of Melbourne: 5.2 per cent

- Edith Cowan University: 5.1 per cent

- Curtin University of Technology: 4.7 per cent

- Deakin University: 4.5 per cent

- Queensland University of Technology: 4.3 per cent

- University of Wollongong: 4.1 per cent

- University of New South Wales: 4 per cent

- University of Tasmania: 3.9 per cent

- Victoria University: 3.8 per cent.

While the majority of ACIS papers were from Australian and New Zealand authors, there was a significant presence of authors from countries elsewhere in the world. The non-Australasian countries that have contributed the most papers between 1990 and 2005 (using first-author country affiliation) are (the number of papers from each country is in parentheses):

- United States (15)

- United Kingdom (13)

- Hong Kong (China) (10)

- Germany (9)

- Norway (9)

- Singapore (7)

- Finland (7)

- South Africa (7).

\section{Conclusion}

In conclusion, it is reiterated that this Australian study is the first component in a wider, continuing, longitudinal study of the IS academic discipline around the world. As reflected in the existing literature, owing to its youth, IS has 
understandably been soul-searching for the past two decades. Information systems as a separate academic discipline is relatively young and yet maturing. The extensive variation observed across the state case studies in curriculum and research foci-as well as the placement and levels of IS in universities in Australia - further attests to its formative stage of evolution. Following are described: 1) the communication of study results; and 2) study limitations.

\section{Communicating study results}

An initial vehicle for communicating the Australian study results was the December 2006 special issue of the AJIS. A consolidation of the Australian state case studies appears (Gable 2007b) in the September 2007 special issue of CAIS, as the Australian state case study in the Pacific-Asia region multiple case study. Many of the lessons learned in relation to research methods and tools are also reported in a 'Methodological learnings' paper (Gable and Smyth 2007) in the same special edition of CAIS.

\section{Limitations}

As acknowledged at various points in this chapter, the study was a learning experience, a major aim being to evolve an approach that could be repeated across time and across regions; as such, its limitations are many, several of which have been specified throughout this chapter. 


\section{References}

Ackoff, R. 1971, 'Towards a system of systems concepts', Management Science, vol. 17, no. 11, pp. 661-71.

Adam, F. and Fitzgerald, B. 2000, 'The status of the information systems field: historical perspective and practical orientation', Information Research, vol. 5, no. 4, viewed 12 March 2006, $<$ http://informationr.net/ir/5-4/paper81.html>

Alavi, M. and Carlson, P. 1992, 'A review of MIS research and disciplinary development', Journal of Management Information Systems, vol. 8, no. 4, pp. 45-62.

Alvesson, M. and Sköldberg, K. 1999, Reflexive Methodology: New Vistas for Qualitative Research, Sage, London.

Ang, A. Y. and Jiwahhasuchin, S. 1998, 'Information systems education in Thailand: a comparison between the views of professionals and academics', Journal of Global Information Management, vol. 6, no. 4, pp. $34-42$.

Avgerou, C., Siemer, J. and Bjørn-Andersen, N. 1999, 'The academic field of information systems in Europe', European Journal of Information Systems, vol. 8, no. 2, pp. 136-53.

Bacon, C. J. and Fitzgerald, B. 2001, 'Research contributions: a systemic framework for the field of information systems', ACM SIGMIS Database, vol. 32, no. 2, pp. 46-67.

Barki, H., Rivard, S. and Talbot, J. 1993, 'A keyword classification scheme for IS research literature: an update', MIS Quarterly, vol. 17, no. 2, pp. 209-26.

Becher, T. 1989, Academic Tribes and Territories, Society for Research into Higher Education and Open University Press, Milton Keynes, England.

Benbasat, I. and Zmud, R. 2003, 'The identity crisis within the IS discipline: defining and communicating the discipline's core properties', MIS Quarterly, vol. 27, no. 2, pp. 183-94.

Chau, P. Y. K. and Kuan, K. K. Y. 2007, 'The information systems academic discipline in Hong Kong-2006', Communications of the Association for Information Systems, vol. 21, no. 3, pp. 49-60.

Chen, W. and Hirschheim, R. 2004, 'A paradigmatic and methodological examination of information systems research from 1991 to 2001', Information Systems Journal, vol. 14, no. 3, pp. 197-235. 
Clarke, R. 2006, 'Key aspects of the history of the information systems discipline in Australia', Australasian Journal of Information Systems, vol. 14, no. 1 , pp. 123-40.

Clarke, R. \& Lo B. 1989, Accreditation Requirements for Information Systems Courses for the Australian Computer Society, ACS, November 1989.

Claver, E., Gonzalez, R. and Llopis, J. 2000, 'An analysis of research in information systems (1981-1997)', Information \& Management, vol. 37, no. 4, pp. 181-95.

Evaristo, J. R. and Karahanna, E. 1997, 'Is North American IS research different from European IS research?', The Data Base for Advances in Information Systems, vol. 28, no. 3, pp. 32-43.

Farhoomand, A. F. and Drury, D. H. 1999, 'A historiographical examination of information systems', Communications of the AIS, vol. 1, no. 19, pp. $1-27$.

Gable, G. G. 2002, State of the Information Systems Academic Discipline in the Pacific Asia Region: A Survey and Multiple Case Study, Proposal to Association for Information Systems (AIS) submitted to AIS Council at ICIS 2002 in Barcelona, [data file], available from http://sky.fit.qut.edu.au/ gable/

Gable, G. G. 2006, 'The information systems discipline in Australian universities: a contextual framework', Australasian Journal of Information Systems, vol. 14, no. 1, pp. 103-22.

Gable, G. G. 2007a, 'The information systems academic discipline in Pacific Asia 2006: a contextual analysis', Communications of the Association for Information Systems, vol. 21, article 1, pp. 1-22.

Gable, G. G. 2007b, 'The information systems academic discipline in Australia 2006', Communications of the Association for Information Systems, vol. 21, article 2, pp. 23-48.

Gable, G. G. and Smyth, R. W. 2007, 'The state of the IS academic discipline in Pacific Asia 2006: methodological learnings', Communications of the Association for Information Systems, vol. 21, article 9, pp. 166-94.

Gable, G. G., Lee, J.-N., Kwahk, K.-Y. and Green, P. 2007, 'Administrative placement of the information systems academic discipline: a comparative SWOT analysis', Communications of the Association for Information Systems, vol. 21, no. 8, pp. 137-65.

Gable, G., Stark, K. and Smyth, R. 2007, 'IS researcher issues', Proceedings of the International Conference on Wireless Communications, Networking and Mobile Computing (WiCom 2007), Shanghai, China, 25-28 July. 
Gregor, S., Lewis, E. and McDonald, C. 2006, 'Case study: the state of information systems in Australian Capital Territory universities', Australasian Journal of Information Systems, vol. 14, no. 1, pp. 177-92.

Huff, S. and Lehmann, H. 2007, 'The information systems academic discipline in New Zealand-2006', Communications of the Association for Information Systems, vol. 21, no. 5, pp. 87-103.

Introna, L. D. 2003, 'Disciplining information systems: truth and its regimes', European Journal of Information Systems, vol. 12, no. 3, pp. 235-40.

Khazanchi, D. and Munkvold, B. E. 2000, 'Is information systems a science? An inquiry into the nature of the information systems discipline', Database for Advances in Information Systems, vol. 31, no. 3, pp. 24-42.

Koronios, A. and Swatman, Paula 2006, 'The state of information systems in Australian universities: South Australia report', Australasian Journal of Information Systems, vol. 14, no. 1, pp. 201-10.

Lee, C.-C. and Liang, T.-P. 2007, 'The information systems academic discipline in Taiwan-2006: a focus on top-tier universities', Communications of the Association for Information Systems, vol. 21, no. 7, pp. 116-36.

Lee, J.-N. and Yoo, S.-W. 2007, 'The information systems academic discipline in Korea-2006: a focus on leading universities', Communications of the Association for Information Systems, vol. 21, no. 4, pp. 61-86.

Lo, B. W. N. 1989, A Survey of Information Systems Educational Programmes in Australian Tertiary Institutions, Working Paper Series No. 1, Department of Information Systems, University of Wollongong.

Metcalfe, M. 2006, 'Using contradictions to appreciate the history of IS education in South Australia', Australasian Journal of Information Systems, vol. 14 , no. 1, pp. 261-72.

Orlikowski, W. and Baroudi, J. J. 1991, 'Studying information technology in organizations: research approaches and assumptions', Information Systems Research, vol. 2, no. 1, pp. 1-28.

Palvia, P., Leary, D., Mao, E., Pinjani, P. and Salam, A. F. 2004, 'Research methodologies in MIS: an update', Communications of the Association for Information Systems, vol. 14, pp. 526-42.

Pervan, G. and Shanks, G. 2004, IS Research Activity in Australia: Results of the 2004 ACPHIS research survey, Presentation to Australasian Conference on Information Systems, December 2004.

Pervan, G. and Shanks, G. 2006, 'The 2005 survey of information systems research in Australia', Australasian Journal of Information Systems, vol. 14, no.

1, pp. 273-80. 
Pollard, C. and Chan, E. S. K. 2006, 'A review of information systems programs in universities in Victoria', Australasian Journal of Information Systems, vol. 14, no. 1, pp. 231-50.

Ridley, G. 2006a, 'Characterising information systems in Australia: a theoretical framework', Australasian Journal of Information Systems, vol. 14, no. 1, pp. $141-62$.

Ridley, G. 2006b, 'The state of information systems in Australian universities - Tasmanian report', Australasian Journal of Information Systems, vol. 14, no. 1, pp. 211-30.

Sherer, S. A. 2002, 'Academic departments of information systems faculty in the US', Journal of Information Systems Education, vol. 13, no. 2, pp. 105-16.

Smyth, R. and Gable, G. 2006, 'Case study: the state of information systems in Queensland universities', Australasian Journal of Information Systems, vol. 14, no. 1, pp. 163-76.

Standing, C., Burn, J. and Lin, C. 2006, 'Information systems in Western Australian universities', Australasian Journal of Information Systems, vol. 14, no. 1, pp. 251-60.

Tan, B. C. Y. and Chan, T. 2007, 'The information systems academic discipline in Singapore 2006', Communications of the Association for Information Systems, vol. 21, no. 6, pp. 104-15.

Underwood, J. and Jordan, E. 2006, 'The state of IS in Australian universities - New South Wales report', Australasian Journal of Information Systems, vol. 14, no. 1, pp. 193-200.

Vessey, I., Ramesh, V. and Glass, R. L. 2002, 'Research in information systems: an empirical study of diversity in the discipline and its journals', Journal of Management Information Systems, vol. 19, no. 2, pp. 129-74.

Walsham, G. 1995, 'Interpretive case studies in IS research: nature and method', European Journal of Information Systems, vol. 4, pp. 74-81.

Whitley, R. 1984a, 'The development of management studies as a fragmented adhocracy', Social Science Information, vol. 23, no. 4-5, pp. 775-818.

Whitley, R. 1984b, The Intellectual and Social Organization of the Sciences, Clarendon Press, Oxford, UK.

Yin, R. K. 2003, Case Study Research: Design and Methods, 3rd edn, Sage Publications, Thousand Oaks. 


\section{Appendix 1.1: The information systems academic discipline in Australian universities - a multi-state case-study protocol}

\section{Overview of the multiple case study}

The project involves a study of IS academia in Australia. From individual case studies in each of the Australian states, and the Australian Capital Territory, an Australian multiple case study report will be prepared to be published in the AJIS (phase one of the study). This research project is planned as a preliminary to a similar study across the Asia-Pacific region.

\section{The study team}

$\begin{array}{llll}\text { QLD } & \text { Guy Gable (editor) } & \text { Bob Smyth } & \\ \text { WA } & \text { Janice Burn } & \text { Craig Standing } & \text { Chad Lin } \\ \text { NSW } & \text { Jim Underwood } & \text { Ernie Jordan } & \\ \text { ACT } & \text { Shirley Gregor } & \text { Ed Lewis } & \text { Craig McDonald } \\ \text { SA } & \text { Paula Swatman } & \text { Andy Koronios } & \text { Mike Metcalfe } \\ \text { VIC } & \text { Carol Pollard } & \text { Elsie Chan } & \\ \text { TAS } & \text { Gail Ridley } & & \end{array}$

\section{Purpose of the case-study protocol}

Since separate researchers will undertake the individual state case studies, this protocol seeks to be somewhat more detailed than might otherwise be necessary. It is hoped that this protocol will facilitate some:

1. comparability across the states

2. consistency across the individual case studies

3. efficiency in the conduct of the case studies, with potential for data gathering and some analysis being delegated to research assistants or other junior researchers.

The protocol draws heavily on the approach suggested by Yin (2003), incorporating some of the ideas of Walsham (1995). In particular, this protocol seeks an interpretive approach directed at what Walsham calls 'rich insight'.

\section{Type of case study}

Each case study should be viewed as an opportunity to collect and record perceptions of the interviewees (as well as other forms of evidence). In keeping with an interpretive slant, subjectivity on the part of the interviewees and the researchers is accepted. The case studies are to be descriptive and to focus on perceived points of differentiation across universities within a state (other, more readily comparable data might be available from existing surveys). The framework used to guide the study provides a theoretical context for the study, 
and was derived from the PhD thesis of team member Gail Ridley. It is expected that a historical perspective on the evolution of IS in each university will inform the current state of IS in the university and across the state.

\section{Background to the current study}

This Australian multi-state case study is a precursor to a wider Pacific-Asia study ('IS-in-PA'). This study seeks to draw on, and complement, other recent or planned studies of the state of the IS discipline, notably those of Avgerou et al. (1999), Huff and Lehmann (2007), and Pervan and Shanks (2006).

\section{Theoretical framework}

There is a body of knowledge that suggests that many of the characteristics of IS are consistent with those observed across emerging disciplines in the early stages of their development. For example, some of the characteristics that manifested themselves in the early evolution of management as a discipline have been seen more recently in the development of IS. Some of these characteristics include:

- a heavy reliance on reference disciplines

- a paucity of theory specific to the discipline

- a perceived lower status than for established disciplines, leading to the adoption of methods from the higher-status disciplines

- limited numbers of textbooks that review the discipline

- poor definition of the boundaries of study

- incorporation organisationally as a subset of an established discipline.

The framework proposed is based on two constructs: 1) the degree of professionalism as a discipline, and 2) maturity as a scientific field. Both are derived from Whitley's theory of scientific change (1984a, 1984b).

The first construct concerns the degree of 'professionalisation' of the discipline, which is expected to increase as the impact of local contingencies decreases. Where a discipline is not highly professionalised, local contingencies such as political pressures have a high impact. Consequently, the degree of professionalisation of IS can be evidenced by the extent of variation in the nature of its research among the 'states' of Australasia over time.

The second construct has been derived from Whitley's three conditions for the establishment of a distinct scientific field:

- scientific reputations become socially prestigious and 'control critical rewards' - that is, those in the discipline have the potential for prestige and power through prominence in that discipline

- standards of research competence and skills become established 
- a unique symbol system is developed that allows the exclusion of outsiders and unambiguous communication between initiates within the discipline.

\section{Approach to data gathering}

Based on evidence deriving from interviews conducted, and supplemented by documentary and other archival evidence, it is expected that you will ultimately develop a rich description of the state of IS across your state. It is intended that interviews be used as the principal form of data gathering. Where available, existing documentary and archival material should be gathered to supplement the interview data and to provide some triangulation of observations. The interviews are to be semi-structured, with emphasis on factors relating to the emergence of IS, broad perceptions of the interviewee on IS in his/her university, points of differentiation and distinctive features of IS in that state. You should seek answers to the broad themes outlined below, using the supplementary questions only as deemed appropriate. Each interview should last about one hour. Where face-to-face interviews are impractical, telephone interviews will suffice. They will normally be of shorter duration (30 minutes plus) than the face-to-face interviews.

\section{Ethical considerations}

You should ensure that all interviews are conducted with due concern for the ethical standards that guide research procedures at the Queensland University of Technology and at your university. Before starting the interview, you should seek from interviewees their written approval to participate in a recorded interview. You should retain one copy of the signed consent, to be stored with the interview recording. The recorded interview need not be transcribed. The recording should be referenced by the interviewer to assist in the preparation of summary interview notes.

\section{Preparation for the interview}

Prospective interviewees should be selected from academics within each (if possible) university running IS courses in your designated state. A minimum of one interviewee per institution is recommended where this is practical. In states where there are several universities, a feasible approach to data gathering might involve just two or three 'full' interviews supported by shorter interviews in the other universities. Where resources permit, it will be useful to interview more than one person from each university as a means of gaining a more balanced perspective. In states with few universities, one-to-one interviews might be better replaced with focus groups. 


\section{Starting interviews}

1. Start the interview by introducing yourself and explaining the purpose of the interview viz. to gather data on the condition of IS in universities in the state. Emphasise that we are seeking particularly broad perceptions on points of differentiation in the approach to IS in the interviewee's university.

2. Outline our agreed definition of IS, as distinct from other ICT disciplines such as computer science and computer engineering.

The original 1994 Asia Pacific Directory of Information Systems Researchers (APDISR) observed, 'The question, "Who is an Information Systems academic?" is not easily answered.' The APDISR goes on to 'loosely define an IS researcher as "one concerned with analysis, design, implementation, evaluation, and management of information systems, from a managerial or user perspective, rather than from a computer science perspective"'. In consultation with your interviewees, therefore, you will need to decide which organisational entities, which parts of the curriculum and which people you consider to relate to IS for the purposes of this study.

\section{Recommended data to be gathered from each interview}

Note that rich data are to be sought as indicated by the italicised headings below. The interviewer might use the specific questions to elicit the sort of data that might be useful if this is overlooked by the interviewee. It is not vital that each question below be asked. We accept that the individual state teams will likely have differing emphases in their data collection and interpretation. We feel this will give richness to the individual reports without unduly affecting comparability. Where interviewees can access relevant statistical data outside the interviews, these matters can be considered by the interviewer without being sought during the interview. You might, however, confirm any such statistical data with interviewees, either at the time of the interview or when interview notes are sent to the interviewee for checking.

\section{Get identifying data and the scope of relevant knowledge.}

1. Confirm the name of the interviewee; the institution the interviewee represents; and the position of the interviewee in that institution.

2. Explain that you are seeking information about IS courses and IS research. Check whether the interviewee is comfortable answering questions about each area in his/her institution. Where the interviewee has knowledge principally with regard to either research or teaching only, you should try to get the name of, and an introduction to, a suitable person to subsequently cover the other area. 
Get a picture of the relative size of the IS presence at the university and the administrative placement of IS.

3. How many people teach IS subjects at the institution?

4. Which administrative groupings (for example, business faculty, school of IT) do the IS teaching staff belong to? Outline how this has evolved over the years.

5. What is the total number of students in your institution? (What is the full-time equivalent?)

Look for approximate numbers. Do not let the discussion bog down in details. Use existing statistical sources if they are readily available to you.

6. What are the undergraduate and postgraduate IS courses offered at your institution (separate course-work courses from research-based courses)?

7. How many students are currently enrolled in each of the IS courses just referred to?

Look for approximate numbers. Do not let the discussion bog down in details. Use existing statistical sources if they are readily available to you.

Get a feeling for the extent to which IS at the university is impacted on by local contingencies.

8. Discuss the extent to which IS curriculum and research at your university is affected by local factors (for example, local industry, political pressures).

9. Do you think that IS is any more or less affected by local factors than other disciplines at your university?

Get a feeling for the extent to which IS is identified as a separate field at the university.

10. Discuss the extent to which IS has a separate identity at your university.

11. What factors distinguish IS subjects and research from those that would be found in business and computer science at your university?

12. Do you feel that your position as an IS academic gives you greater or lesser status in your university relative to your colleagues in business and computer science?

13. Is there anything about the terminology of IS at your university that would be foreign/unfamiliar to your business and computer science colleagues?

Get a picture of the distinctive features of the IS curriculum at the university.

14. Discuss the extent to which IS curriculum and research at your university is affected by local factors (for example, local industry, political pressures).

15. Discuss the place of service teaching of IS at your institution, as opposed to teaching in IS courses. 
16. What do you see as distinctive features (if any) of IS as taught at your institution? Themes?

17. How do you see your institution's IS courses in relation to those offered by other institutions in your state? Similar in emphasis? Complementary? Sharply different?

18. Are there particular tools, techniques or technologies used in the teaching of IS at your university that are distinctive?

19. Approximately what percentage of your IS course-work students are 'international students'? Which nations are represented most strongly? Has there been any significant change in this pattern in the past three years?

20. Approximately what percentage of your IS research students are 'international students'? Which nations are represented most strongly? Has there been any significant change in this pattern in the past three years?

21. What proportion of IS students at your institution are taught by 'distance education'? Discuss the form/s of distance education used and where most of these distance students are located (locally, interstate, overseas). Is your university distinctive in its approach to IS distance education?

22. To what extent have enrolments in IS at your institution been affected by the recent downturn in ICT employment?

23. What do you see as the main issues relating to the teaching of IS in your institution?

24. What changes are planned for teaching/curriculum in IS in your institution in the next three years?

\section{Get a picture of the distinctive features of IS research at the university.}

25. How would you rate the average level of research output across the IS staff in your institution? Discuss your assessment.

26. What is the balance between IS research and IS teaching in your institution, with respect to incentives for each?

27. How is IS research primarily funded in your institution?

28. What are the main areas of focus in IS research in your institution?

29. What are the main IS research methods used in your institution?

30. How many students are currently enrolled in IS PhDs in your institution? Has there been a decrease or increase in these numbers in the past three years?

31. To what extent do you think that the emphasis of research in your institution is consistent with IS research themes in other institutions in your state?

32. Discuss conference attendance by IS researchers in your institution: on average, how many conferences a year would your IS researchers attend? Which conferences are most popular with your IS researchers, and why? 
33. What local factors have an impact on IS research in your state?

34. What do you see as the main issues related to IS research in your institution?

35. What changes are planned for IS research in your institution in the next three years? Changes of focus? Changes in funding? Changes in research group structure?

\section{Get interviewee's perception of the characteristics of IS in universities in that state.}

36. What general information can you provide about IS teaching and research across tertiary education institutions in your state?

Get interviewee's perception of the key people in their region who have had an impact on IS in universities in that state.

37. Can you name some significant individuals (politicians, bureaucrats, academics, members of professional societies, members of advisory committees) who have had a significant impact on IS in your university? Outline the nature of the impact in each case.

38. Can you give names of suitable people from other institutions in your state who might be usefully interviewed for this study?

Conclude the interview, with thanks to the interviewee. Give a commitment on when the interview notes will be made available to the interviewee for checking. Seek permission for access to the interviewee again for any incidental follow-up.

\section{Acknowledgements}

This study of the IS academic discipline in Australian universities has made significant demands on Queensland University of Technology (QUT), in terms of the time and efforts of Professor Gable, Dr Robert Smyth and Karen Stark; the provision of the study team web site; facilities for conferencing; and numerous other resources to support the project. I wish to acknowledge here my appreciation to QUT and the Faculty of Information Technology for this significant provision of resources to make the study achievable.

A project of this magnitude involves a large number of people. Many have contributed their valuable time to the study. In addition to the core study team members, we express our sincere thanks to: 1) state report reviewers, who reviewed a draft of one (or more) of the state case reports; 2) interviewees, who gave their time for evidence collection; and 3) special issue reviewers. We offer our special thanks to the special issue reviewers, who reviewed the complete special issue, offering ideas and advice that were particularly valuable and influential in finalising the papers. Thanks also to the AIS for endorsing the study and for seed funding. Thanks are due also to the ACS for supporting and seed funding the ACIS Archival Analysis. 
Finally, my personal thanks to Bob Smyth for his untiring support as project manager throughout the study duration. We could not have made it without him; his input throughout has been substantial. My sincere thanks also to Karen Stark, who crafted sections of the overview, whose due diligence ensured maximum accuracy and completeness and whose meticulous eye introduced a level of presentation quality otherwise not possible within the project's scope. 